\title{
Campylobacter concisus Impairs Sodium Absorption in Colonic Epithelium via ENaC Dysfunction and Claudin-8 Disruption
}

\author{
Praveen Kumar Nattramilarasu ${ }^{1}$ (D), Roland Bücker ${ }^{1}$, Fábia Daniela Lobo de Sá ${ }^{1}{ }^{1}$, \\ Anja Fromm ${ }^{1}$ D, Oliver Nagel ${ }^{1}$, In-Fah Maria Lee ${ }^{1}$, Eduard Butkevych ${ }^{1}$, Soraya Mousavi ${ }^{2}$, \\ Claudia Genger ${ }^{2}$, Sigri Kløve ${ }^{2}$, Markus M. Heimesaat ${ }^{2}$, Stefan Bereswill ${ }^{2}$, \\ Michal R. Schweiger ${ }^{3}$, Hans Linde Nielsen ${ }^{4,5}$, , Hanno Troeger ${ }^{6}$ and Jörg-Dieter Schulzke ${ }^{1, * \mathbb{D}}$ \\ 1 Institute of Clinical Physiology/Nutritional Medicine, Medical Department, Division of Gastroenterology, \\ Infectiology and Rheumatology, Charité-Universitätsmedizin Berlin, 12203 Berlin, Germany \\ 2 Institute of Microbiology, Infectious Diseases and Immunology, Charité-Universitätsmedizin Berlin, \\ Campus Benjamin Franklin, 14195 Berlin, Germany \\ 3 Laboratory for Epigenetics and Tumour genetics, University Hospital Cologne and Centre for Molecular \\ Medicine Cologne, 50931 Cologne, Germany \\ 4 Department of Clinical Microbiology, Aalborg University Hospital, 9000 Aalborg, Denmark \\ 5 Department of Clinical Medicine, Aalborg University, 9000 Aalborg, Denmark \\ 6 Medical Department, Division of Gastroenterology, Infectiology and Rheumatology, \\ Charité-Universitätsmedizin Berlin, 12203 Berlin, Germany \\ * Correspondence: joerg.schulzke@charite.de
}

Received: 1 November 2019; Accepted: 31 December 2019; Published: 7 January 2020

check for updates

\begin{abstract}
The epithelial sodium channel (ENaC) can increase the colonic absorptive capacity for salt and water. Campylobacter concisus is a common pathogenic epsilonproteobacterium, causing enteritis and diarrhea. It can induce barrier dysfunction in the intestine, but its influence on intestinal transport function is still unknown. Therefore, our study aimed to characterize $C$. concisus effects on ENaC using the HT-29/B6-GR/MR (epithelial cell line HT-29/B6 transfected with glucocorticoid and mineralocorticoid receptors) cell model and mouse colon. In Ussing chambers, C. concisus infection inhibited ENaC-dependent $\mathrm{Na}^{+}$transport as indicated by a reduction in amiloride-sensitive short circuit current $(-55 \%, n=15, p<0.001)$. This occurred via down-regulation of $\beta$ - and $\gamma$-ENaC mRNA expression and $\mathrm{ENaC}$ ubiquitination due to extracellular signal-regulated kinase (ERK)1/2 activation, predicted by Ingenuity Pathway Analysis (IPA). In parallel, C. concisus reduced the expression of the sealing tight junction (TJ) protein claudin-8 and induced claudin-8 redistribution off the TJ domain of the enterocytes, which facilitates the back leakage of $\mathrm{Na}^{+}$ions into the intestinal lumen. In conclusion, C. concisus caused ENaC dysfunction via interleukin-32-regulated ERK1/2, as well as claudin-8-dependent barrier dysfunction-both of which contribute to $\mathrm{Na}^{+}$malabsorption and diarrhea.
\end{abstract}

Keywords: sodium transport; epithelial sodium channel, extracellular signal-regulated kinase, Campylobacter concisus; diarrhea; tight junction; claudin-8

\section{Introduction}

Campylobacter concisus (C. concisus) is a Gram-negative, hydrogen $\left(\mathrm{H}_{2}\right)$-utilizing microorganism, first identified in periodontal pockets [1]. Extensive colonization by C. concisus and other anaerobic bacteria contributes to inflammation of the oral mucosa [2,3]. A clinical study first detected C. concisus, zoonotic Campylobacter jejuni/Campylobacter coli and other Campylobacter spp. in fecal samples of children 
with diarrhea, whereas fecal samples of adult patients with diarrhea mainly contained C. jejuni/C. coli without $C$. concisus [4]. C. concisus is also a frequent cause of diarrhea in immunocompromised patients [5]. However, C. concisus has been identified in oral and fecal samples of healthy patients with the same frequency as in diarrheal patients [6,7]. Thus, it has been difficult to determine whether C. concisus has a role in the pathophysiology of acute infective diarrhea.

A large cohort study revealed that $C$. concisus infection caused watery stools in most patients with diarrhea, which was prolonged compared to patients with diarrhea caused by C. jejuni [8]. Furthermore, $C$. concisus promoted intestinal barrier dysfunction [9], although the effects of $C$. concisus on intestinal transport function remains unclear. While sodium-hydrogen exchanger 3 (NHE3)-mediated electroneutral $\mathrm{Na}^{+}$transport predominates in ileum and proximal colon, epithelial sodium channel $(\mathrm{ENaC})$-mediated electrogenic $\mathrm{Na}^{+}$absorption is more important in distal colon, especially when activated by corticoids in diarrheal states [10]. ENaC is composed of three subunits $(\alpha, \beta$ and $\gamma$ ) [11]. $\alpha$-ENaC is constitutively expressed, whereas $\beta$ - and $\gamma$-ENaC expression is regulated by gluco- and mineralocorticoids [12]. Enhanced $\mathrm{Na}^{+}$absorption via activated $\mathrm{ENaC}$ in the distal colon is accompanied by transcriptional up-regulation of $\beta$ - and $\gamma$-ENaC-subunits $[13,14]$.

To study ENaC activity in vitro, we used HT-29/B6-GR/MR cell model, in which classical human intestinal epithelial cells HT-29/B6 are stably transfected with glucocorticoid (GR) and mineralocorticoid (MR) receptors. Glucocorticoid receptor (GR)/mineralocorticoid receptor (MR) activation is crucial for $\mathrm{ENaC}$ activity in this in vitro model [15]. Furthermore, other regulatory inputs, such as the phosphorylation and activation of mitogen-activated protein kinase (MAPK) p38, extracellular signal-regulated kinase (ERK), c-Jun N-terminal kinase (JNK) and signal transducer and activator of transcription 6 (STAT-6), influence ENaC function [16,17]. Among different MAPK enzymes, ERK activation plays a central role in inhibiting $\mathrm{ENaC}$ function in inflammatory conditions such as ulcerative colitis, lymphocytic colitis and Crohn's disease [18-20].

C. concisus also induces intestinal epithelial barrier dysfunction through apoptosis and moderate modifications to tight junctions (TJ) [9], which supports the concept of a leak-flux diarrheal pathomechanism. The main aim of this study was to determine whether $C$. concisus impairs ENaC-dependent $\mathrm{Na}^{+}$transport in the colon, which would implicate $\mathrm{Na}^{+}$malabsorption in the pathogenesis of diarrhea caused by C. concisus.

TJs are important components of the intestinal epithelial barrier. They seal the paracellular space between enterocytes in the intestinal epithelium (fence function) [21]. Although the primary role of most TJ proteins like occludin, junctional adhesion molecules (JAM) and tricellulin in intestinal epithelia is to seal the paracellular spaces [22], some TJ proteins of the claudin family (e.g., claudin-2 and -15) act as paracellular channels (gate function) for water and ions [23,24]. In the colon, claudin-8 seals the lateral paracellular space and forms a barrier to prevent back leakage of absorbed $\mathrm{Na}^{+}$into the lumen [25]. In a previous study, we found claudin-8 to be down-regulated in parallel with impaired ENaC-mediated electrogenic $\mathrm{Na}^{+}$absorption in human colon during acute C. jejuni infection [26]. However, it remains unclear whether C. concisus might also promote down-regulation of claudin-8, which could contribute to diarrhea. Therefore, in addition to an electrophysiological approach to determine the regulatory effects of $\mathrm{C}$. concisus on $\mathrm{ENaC}$ function, we investigated at a molecular level the effects of $C$. concisus on paracellular barrier disruption, particularly claudin- 8 down-regulation, in colonic epithelial cells.

\section{Results}

\subsection{Campylobacter concisus Impairs Sodium Absorption via ENaC Dysfunction In Vitro}

ENaC-dependent $\mathrm{Na}^{+}$absorption in vitro was studied using HT-29/B6-GR/MR colonic cell monolayers. We then established a model of infected HT-29/B6-GR/MR (epithelial cell line HT-29/B6 transfected with glucocorticoid receptors (GR) and mineralocorticoid receptors (MR); [15]) cells to study the effects of $C$. concisus on ENaC-dependent $\mathrm{Na}^{+}$absorption (see also Methods, Section 4.1). Polarized and confluent cell monolayers were treated with dexamethasone, butyrate and aldosterone 
(DBA) to induce glucocorticoid (GR) and mineralocorticoid (MR) receptors as a means of activating ENaC-dependent $\mathrm{Na}^{+}$absorption prior to infection. An increase in amiloride-sensitive short circuit current ( $\mathrm{I}_{\mathrm{SC}}$ in $\mu \mathrm{A} / \mathrm{cm}^{2}$ ) was observed after DBA stimulation compared with unstimulated controls and recorded as $\Delta \mathrm{I}_{\mathrm{SC}}$ (Figure 1). Forty-eight hours post-infection, a significant reduction in $\Delta \mathrm{I}_{\mathrm{SC}}$ was observed in C. concisus-infected cell monolayers, which was similar to that seen with $C$. jejuni infection (Figure 1).

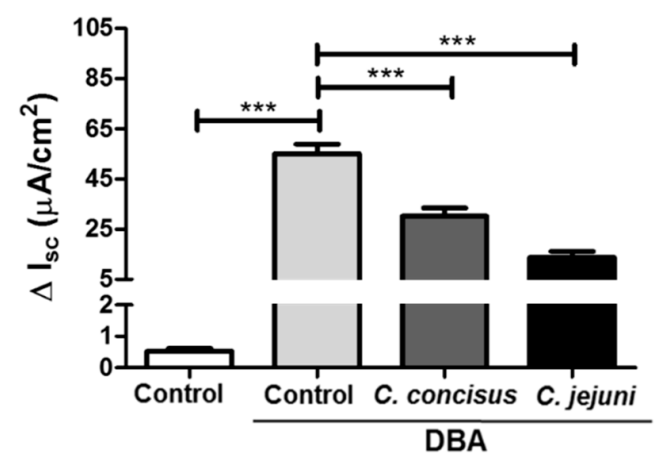

Figure 1. Epithelial sodium channel (ENaC) impairment in HT-29/B6-GR/MR (epithelial cell line HT-29/B6 transfected with glucocorticoid and mineralocorticoid receptors) cells $48 \mathrm{~h}$ after Campylobacter concisus and Campylobacter jejuni infections. Changes in short circuit current $\left(\Delta \mathrm{I}_{\mathrm{SC}}\right.$ in $\left.\mu \mathrm{A} / \mathrm{cm}^{2}\right)$ were recorded in Ussing chambers followed by $100 \mu \mathrm{M}$ amiloride addition to the apical compartment of the Ussing chamber $\left(n=15,{ }^{* * *} p<0.001\right)$. HT-29/B6-GR/MR cells were stimulated with DBA from both apical and basolateral sides of the cell monolayers. DBA; glucocorticoid dexamethasone (D, $50 \mathrm{nM})$, butyrate (B, $2 \mathrm{mM}$ sodium salt) and mineralocorticoid aldosterone (A, $3 \mathrm{nM})$.

To confirm that HT-29/B6-GR/MR cells retained functional viability at this time point, electrogenic chloride $\left(\mathrm{Cl}^{-}\right)$secretion was determined after the addition of prostaglandin $\mathrm{E}_{2}$ (PGE2) and theophylline (both acting via cyclic adenosine monophosphate (cAMP) stimulation), or the cholinergic agonist carbachol (acting via calcium as second messenger). No significant difference in the increase in ISC was observed between controls and C. concisus-infected cell monolayers, either in response to PGE2 and theophylline, or to carbachol treatment (Figure 2). This confirmed that cells $48 \mathrm{~h}$ post-infection were as functionally viable as control cells.

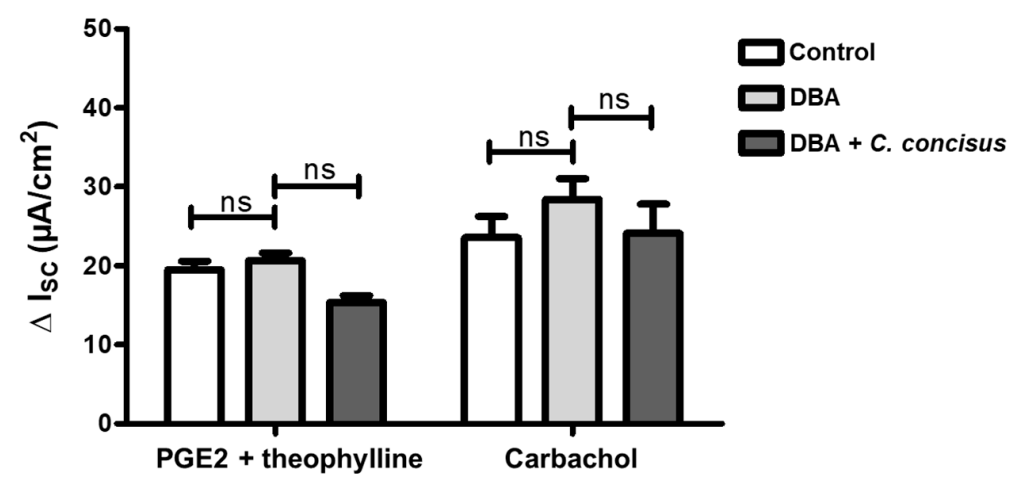

Figure 2. Functional viability of HT-29/B6-GR/MR cell monolayers $48 \mathrm{~h}$ after Campylobacter concisus infection as indicated by chloride $\left(\mathrm{Cl}^{-}\right)$channel activation. $\mathrm{Cl}^{-}$secretion was determined as peak increase in short circuit current $\left(\Delta \mathrm{I}_{\mathrm{SC}}\right.$ in $\left.\mu \mathrm{A} / \mathrm{cm}^{2}\right)$ 2-3 min after addition of Prostaglandin E2 (PGE2) (10 $\mu \mathrm{M}$, basolateral side) and theophylline ( $10 \mathrm{mM}$, apical and basolateral side) to the Ussing chamber. Peak $\Delta \mathrm{I}_{\mathrm{SC}}$ was also measured 2-3 min after addition of carbachol $(100 \mu \mathrm{M}$, basolateral side). C. concisus-infected cell monolayers were compared to untreated and DBA-stimulated controls $(n=4-5$ each, ns $=$ not significant). DBA = dexamethasone, butyrate, and aldosterone. 


\subsection{Campylobacter concisus Down-Regulates the mRNA Expression of $\beta$ - and $\gamma$-ENaC Subunits}

C. concisus was associated with a significant decrease in the mRNA expression of $\beta$ - and $\gamma$-ENaC subunits compared with DBA-stimulated controls, whereas $\alpha$-ENaC subunit (SCNN1A) mRNA expression was not significantly changed (Figure 3). Thus, C. concisus down-regulated the mRNA expression of $\beta$ - and $\gamma$-ENaC genes (SCNN1B, SCNN1G) might be sufficient to impair ENaC-mediated $\mathrm{Na}^{+}$absorption.

A

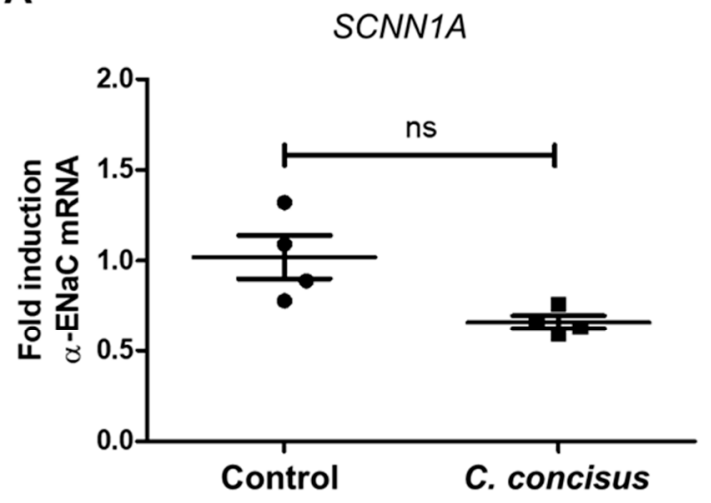

B

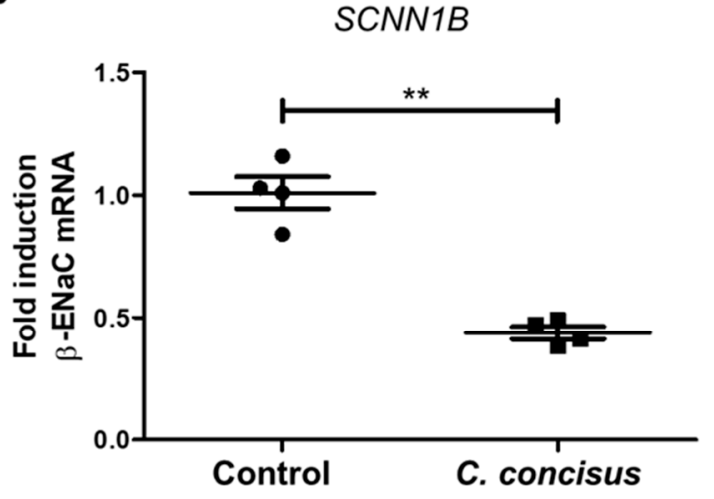

C

\section{SCNN1G}

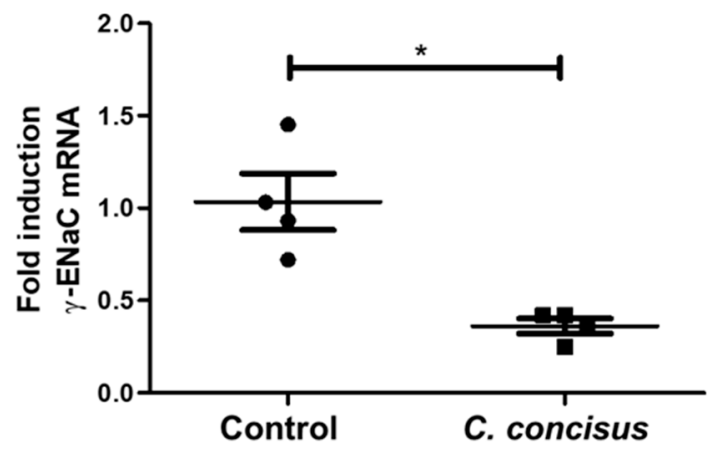

Figure 3. mRNA expression changes in ENaC subunits $(-\alpha,-\beta,-\gamma)$ in HT-29/B6-GR/MR cells $48 \mathrm{~h}$ after Camplyobacter concisus infection through RT-qPCR. (A) $\alpha$-ENaC gene (SCNN1A) mRNA expression in DBA-stimulated controls and $C$. concisus-infected cell monolayers $(n=4$ each, ns $=$ not significant, $p>0.05)$. (B) $\beta$-ENaC gene $(S C N N 1 B)$ mRNA expression in DBA-stimulated controls and C. concisus-infected cell monolayers $\left(n=4\right.$ each, $\left.{ }^{* *} p<0.01\right)$. (C) $\gamma$-ENaC gene $(S C N N 1 G)$ mRNA expression in DBA-stimulated controls and C. concisus-infected cell monolayers $\left(n=4\right.$ each, $\left.{ }^{*} p<0.05\right)$. Changes in $\mathrm{ENaC}$ subunit mRNA expression in DBA-stimulated controls with respect to unstimulated controls are indicated in Supplementary Figure S1. DBA = dexamethasone, butyrate, and aldosterone.

In addition, we determined the mRNA expression of ENaC subunits $(-\alpha,-\beta,-\gamma)$ in unstimulated controls, as well as in DBA-stimulated controls and C. concisus-infected cells. $\alpha$-ENaC subunit (SCNN1A) mRNA expression was not significantly altered after DBA-stimulation (Supplementary Figure S1A), whereas $\beta$ - and $\gamma$-ENaC (SCNN1B, SCNN1G) mRNA expressions were significantly increased with DBA stimulation (Supplementary Figure S1B,C).

Gene expression analysis of RNA-Seq data revealed that 1667 genes were affected $(p<0.05) 48 \mathrm{~h}$ after $C$. concisus infection. RNA-Seq data are publicly available at Gene Expression Omnibus (GEO) archive under National Centre for Biotechnology Information (NCBI) website with GEO accession ID 141217 [Campylobacter concisus impairs sodium absorption via ENaC dysfunction and claudin-8 disruption. Available online: https://www.ncbi.nlm.nih.gov/gds/?term=GSE141217 (1 January 2020)]. The $p$-values, adjusted for multiple testing using the Benjamini-Hochberg procedure, revealed that 
186 genes were differentially expressed (adjusted $p<0.05$ )—of which, 66 genes were up-regulated, and 120 genes were down-regulated (Supplementary Table S1). Importantly, the mRNA expression of the pro-inflammatory cytokine interleukin-32 (IL-32) was increased in HT-29/B6-GR/MR cell monolayers $48 \mathrm{~h}$ after $\mathrm{C}$. concisus infection (Figure 4). Furthermore, the downstream signaling pathways and upstream regulators modulating $\mathrm{ENaC}$ function was evaluated by bioinformatics prediction using Ingenuity Pathway Analysis (IPA) software (Supplementary Table S2).

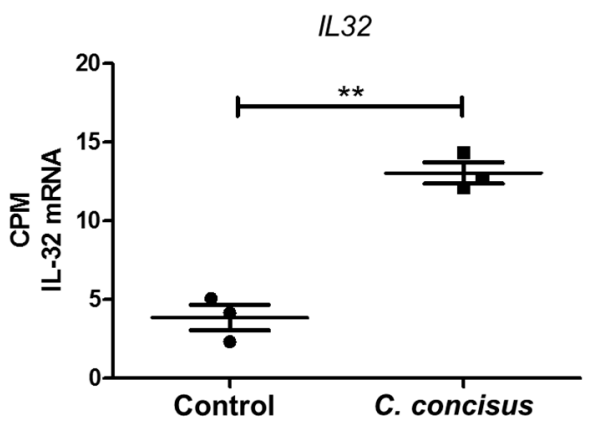

Figure 4. mRNA expression changes in interleukin-32 in HT-29/B6-GR/MR cells $48 \mathrm{~h}$ after Campylobacter concisus infection. The mRNA expression of the IL-32 gene (IL32) in DBA-stimulated controls and C. concisus-infected cell monolayers expressed in counts per million (CPM) calculated by differential gene expression analysis using RNA-Seq $(n=3, * * p<0.01)$. DBA $=$ dexamethasone, butyrate, and aldosterone.

Furthermore, we analyzed the mRNA expression of different absorptive and secretory transporters that influence the $\mathrm{Na}^{+}$absorption and ENaC function after $C$. concisus infection through RNA-seq data (Supplementary Table S2). It revealed that the mRNA expression of $\mathrm{Na}^{+} \mathrm{K}^{+} \mathrm{ATPase}$ was not down-regulated after $C$. concisus infection. The mRNA expression of secretory chloride channels $\mathrm{Na}-\mathrm{K}-\mathrm{Cl}$ cotransporter 1 (NKCC1) and calcium-activated chloride channels (CaCC) was not up-regulated (as would have been expected for a diarrheal state) after C. concisus infection. Cystic fibrosis transmembrane conductance regulator (CFTR) does not impact the inhibition of ENaC function by $C$. concisus either, as the mRNA expression of CFTR was not up-regulated but rather down-regulated. The mRNA expression of NHE3 was not changed after C. concisus infection, which might imply the unaltered electroneutral $\mathrm{NaCl}$-absorption during C. concisus infection.

\subsection{C. jejuni and C. concisus Dysregulate ENaC Function via ERK Activation}

Forty-eight hours post-infection, Western blots of phosphorylated ERK (p-ERK1/2) and total ERK (ERK1/2) $15 \mathrm{~min}$ after DBA stimulation and Campylobacter spp. infection were performed. Phosphorylation of isoform ERK1 (44 kDa band) and ERK2 (42 kDa band) were increased by both C. concisus and C. jejuni (Figure 5A).

Densitometry analysis revealed that $C$. concisus and $C$. jejuni increased ERK phosphorylation after DBA stimulation (Figure 5B), indicating that C. concisus and C. jejuni induced ERK activation in parallel with ENaC dysfunction in HT-29/B6-GR/MR cells.

To determine whether $C$. concisus-induced ERK activation caused functional impairment of $\mathrm{ENaC}$, the specific inhibitor U0126 was used to block ERK activation by upstream inhibition of MEK. C. concisus-induced ENaC dysfunction was then tested again during inhibition of ERK activation. Based on measurements of the amiloride-sensitive increase in ISC $48 \mathrm{~h}$ post-infection, U0126 significantly decreased the damaging effect of $C$. concisus infection on ENaC (Figure 6), suggesting that ERK blockade attenuates $C$. concisus-induced $\mathrm{ENaC}$ dysfunction. 
A

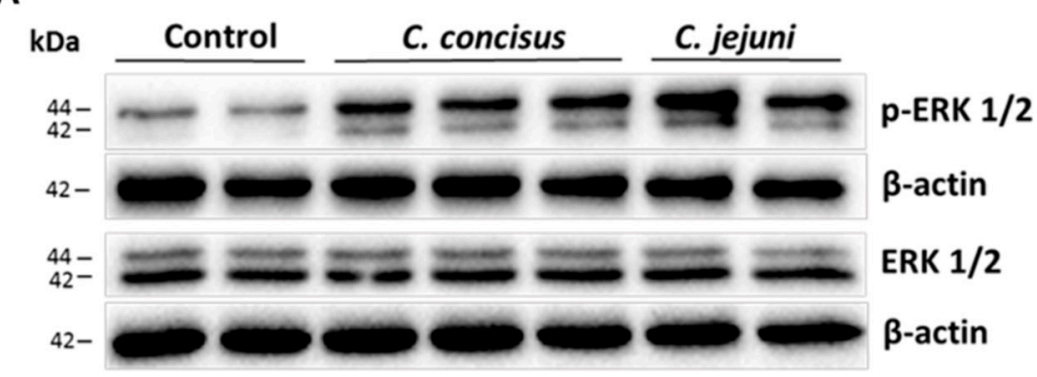

B

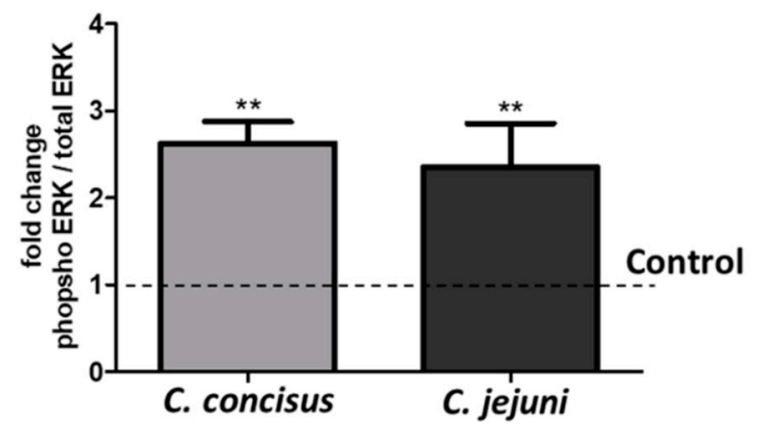

Figure 5. Activation of ERK pathway in HT-29/B6-GR/MR cell monolayers $48 \mathrm{~h}$ after Campylobacter concisus and Campylobacter jejuni infections. (A) Western blots of phosphorylated extracellular signal-regulated kinase (ERK) (p-ERK1/2) and total ERK (ERK1/2) $15 \mathrm{~min}$ after DBA stimulation and C. concisus or C. jejuni infection. (B) Densitometric analysis of Western blots shown as bar graphs representing fold-change in the band intensity ratio of p-ERK1/2 to ERK1/2 (normalized to $\beta$-actin) in C. concisus and C. jejuni infections compared with DBA-stimulated controls, indicated by dotted line $\left(n=4-6\right.$ each, $\left.{ }^{* *} p<0.01\right)$. DBA $=$ dexamethasone, butyrate, and aldosterone.

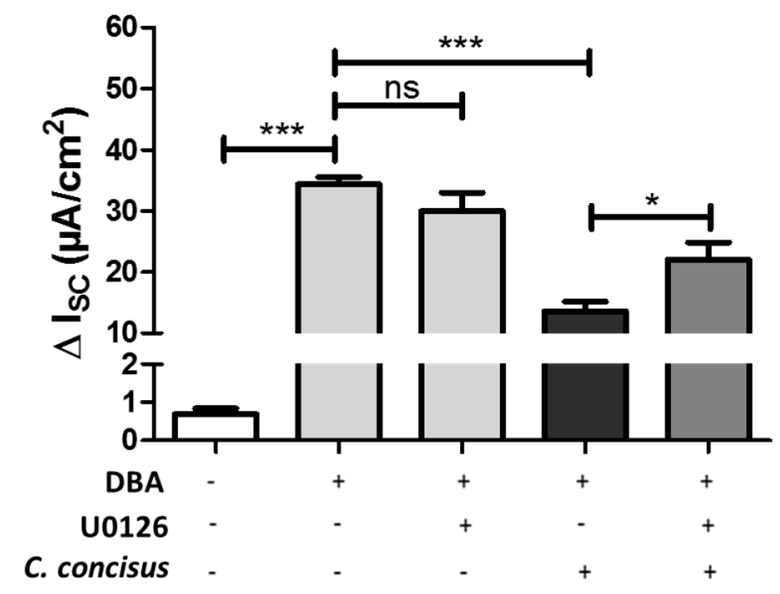

Figure 6. ERK inhibition by U0126 ameliorates the functional impairment of ENaC by Campylobacter concisus in HT-29/B6-GR/MR cell monolayers. The specific ERK inhibitor U0126 (10 $\mu \mathrm{M})$ was applied to the cell monolayers $2 \mathrm{~h}$ before $C$. concisus infection. Parallel control monolayers were only stimulated by DBA (dexamethasone, butyrate, and aldosterone) without infection. Amiloride-sensitive short circuit current $\left(\mathrm{I}_{\mathrm{SC}}\right)$ was recorded $48 \mathrm{~h}$ post-infection to determine $\mathrm{ENaC}$ function. The decrease in short circuit current was measured $20 \mathrm{~min}$ after addition of amiloride $(100 \mu \mathrm{M})$ to the apical side $\left(n=6-8,{ }^{*} p<0.05\right.$, *** $p<0.001, \mathrm{~ns}=$ not significant).

2.4. Campylobacter concisus Decreases Transepithelial Electrical Resistance and Promotes Changes in Tight Junction Protein Expression

To investigate the barrier function of infected cell monolayers $48 \mathrm{~h}$ post-infection, transepithelial electrical resistance (TER) was measured $20 \mathrm{~min}$ after adding amiloride, when ENaC was completely 
blocked. Under these conditions, TER reflected paracellular sealing by TJ proteins. In C. concisus-infected cell monolayers, TER $48 \mathrm{~h}$ post-infection was decreased compared with DBA-stimulated controls (Figure 7A). This is direct evidence that C. concisus impaired paracellular barrier function. We also examined changes in TJ integrity at the molecular level, and using RT-qPCR, found claudin-8 (CLDN8) mRNA expression to be decreased (Figure 7B).

A

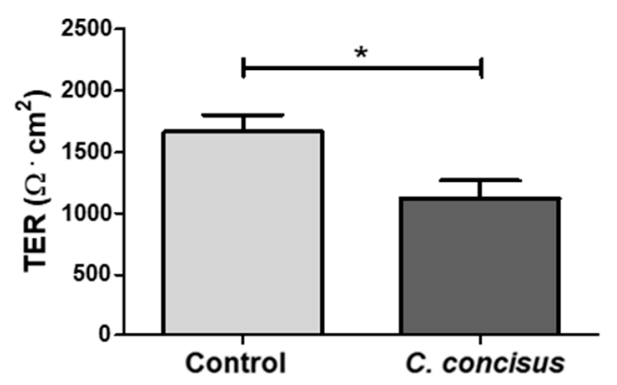

C

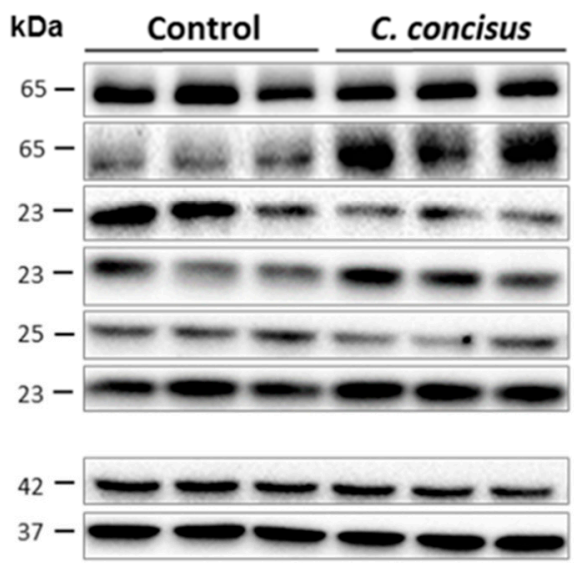

B

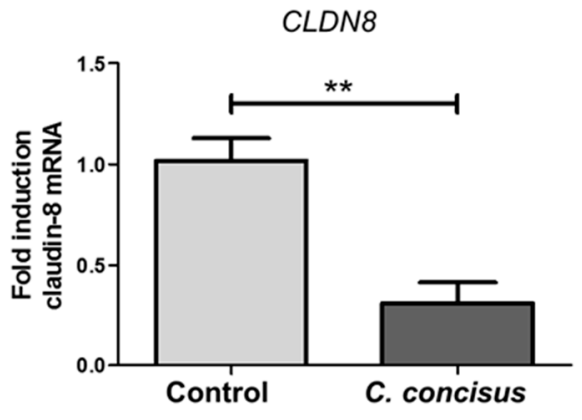

Figure 7. Changes in TER and tight junction protein expression changes in HT-29/B6-GR/MR cell monolayers $48 \mathrm{~h}$ after Campylobacter concisus infection. (A) Transepithelial resistance (TER) was measured $20 \mathrm{~min}$ after addition of amiloride $(100 \mu \mathrm{M})$. C. concisus-infected cell monolayers were compared with DBA-stimulated controls $\left(n=7-8,{ }^{*} p<0.05\right)$. (B) Claudin-8 (CLDN8) mRNA expression in C. concisus-infected cell monolayers compared with DBA-stimulated controls $\left(n=4,{ }^{* *} p<0.01\right)$. (C) Western blots and the corresponding densitometric analysis were performed to detect changes in tight junction protein expression after C. concisus infection compared with controls after DBA stimulation $\left(n=3-5,{ }^{*} p<0.05,{ }^{* *} p<0.001, \mathrm{~ns}=\right.$ not significant). DBA = dexamethasone, butyrate, and aldosterone.

We also analyzed the expression of different TJ proteins by Western blotting and densitometric analysis, which indicated that $C$. concisus decreased claudin-8 expression and increased occludin expression when compared with DBA-stimulated controls (Figure 7C). The expression of the other TJ proteins was not affected by C. concisus infection.

In order to further study the functional importance of this change in claudin-8, parallel experiments were done to determine the effect of $C$. concisus infection on the subcellular distribution of claudin- 8 using confocal laser-scanning microscopy (CLSM). We observed subcellular redistribution of claudin-8 protein signals away from the TJ. Z-stack analysis of CLSM images revealed that claudin-8 was delocalized from TJs and accumulated as intracellular aggregates in C. concisus-infected cell monolayers, whereas clear co-localization of zonula occludens protein-1 (ZO-1) and claudin-8 was observed in TJs in control cell monolayers (Figure 8). 

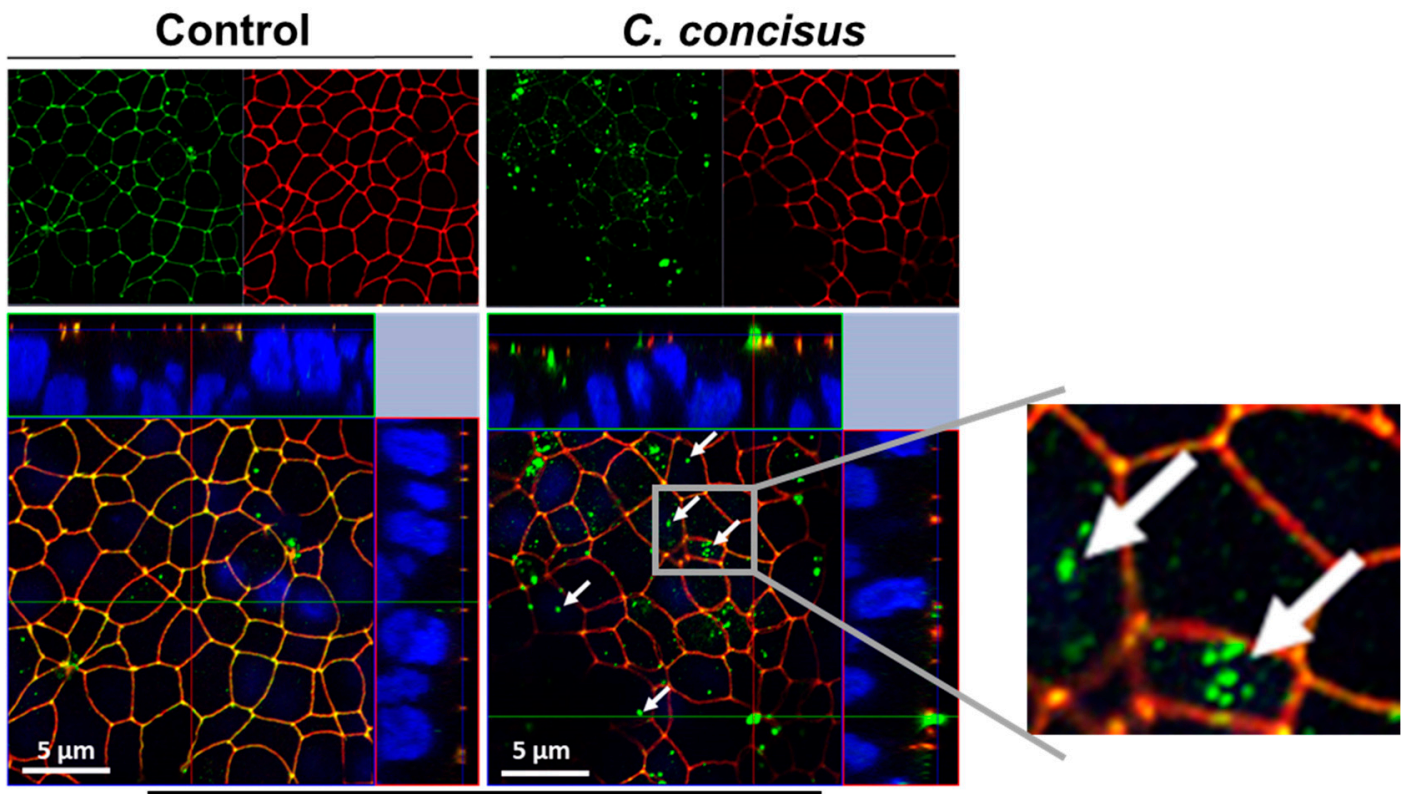

ZO-1 nucleus claudin-8

Figure 8. Subcellular redistribution of claudin-8 in Campylobacter concisus-infected HT-29/B6-GR/MR cell monolayers $48 \mathrm{~h}$ post-infection. Claudin-8 (green) and zonula occludens protein-1 (ZO-1) (red) co-localized in the tight junction of DBA-stimulated control monolayers. Nuclei (blue) were stained by 4'-6-diamidino-2-phenylindole dihydrochloride (DAPI). In C. concisus-infected cell monolayers, claudin-8 was redistributed from continuous tight junction strands into intracellular compartments, indicated by white arrows. DBA = dexamethasone, butyrate, and aldosterone.

To confirm cell viability $48 \mathrm{~h}$ after $\mathrm{C}$. concisus infection, cell proliferation rate and cytotoxicity of the cells were tested using the CCK-8 (Cell Counting Kit-8) assay. This revealed no significant differences in the cell viability after $C$. concisus infection when compared with controls (Figure 9), indicating that C. concisus-induced paracellular barrier defects were independent of cytotoxicity.

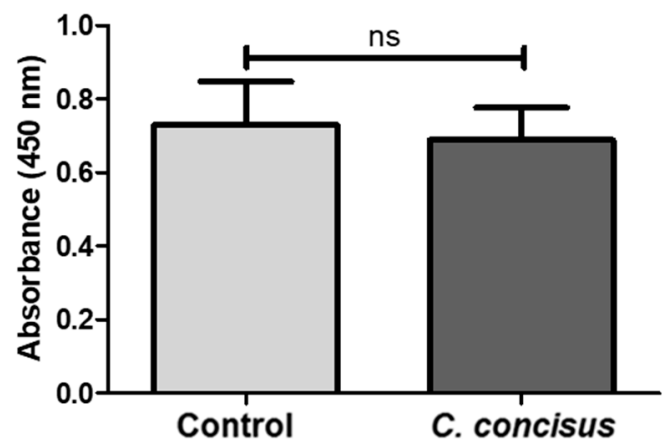

Figure 9. Evaluation of cell viability in Campylobacter concisus-infected HT-29/B6-GR/MR cell monolayers $48 \mathrm{~h}$ post-infection. Absorbance values were recorded at $450 \mathrm{~nm}$ with a reference wavelength of $600 \mathrm{~nm}$ in DBA-stimulated control cells and C. concisus-infected cells, which reflected cellular activity $2 \mathrm{~h}$ after addition of water-soluble tetrazolium salt (WST-8 in the CCK8 assay; $n=8$, ns $p>0.05$, ns = not significant). DBA = dexamethasone, butyrate, and aldosterone.

\subsection{Campylobacter concisus Impairs Sodium Absorption via ENaC in the Colon of $I L-10^{-/}$Mouse}

The abiotic IL-10-/- mouse is an ideal model to study the functionality of inflamed intestine following experimental Campylobacter jejuni infection $[27,28]$. This mouse model was used to determine the transport effects of $C$. concisus in vivo, particularly ENaC-mediated $\mathrm{Na}^{+}$absorption in infected distal colon. Similar to our in vitro cell monolayer model, changes in Isc across tissues obtained from 
infected IL-10 $10^{-/}$mice were measured in Ussing chambers. Six days post-infection, C. concisus infection in IL-10 $-/-$ mouse colon caused a decrease in the amiloride-sensitive ISC $_{\mathrm{S}}$ when compared with control mice, indicating marked ENaC dysfunction (Figure 10).

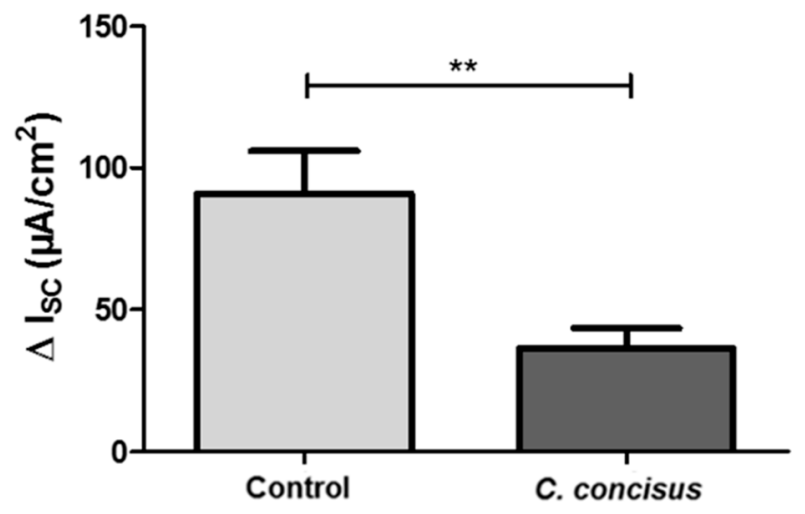

Figure 10. Impaired $\mathrm{ENaC}$ function in colon of Campylobacter concisus-infected abiotic IL-10-/- mice 6 days post-infection. Colon specimens were obtained from infected mice and stimulated with the mineralocorticoid aldosterone $(3 \mathrm{nM})$ in the Ussing chamber for $6 \mathrm{~h}$. The colon samples of IL-10-/mice infected with commensal Escherichia coli were used as controls. The decrease in short circuit current $\left(\Delta \mathrm{I}_{\mathrm{SC}} ; \mu \mathrm{A} / \mathrm{cm}^{2}\right) 20 \mathrm{~min}$ after addition of amiloride $(100 \mu \mathrm{M})$ was measured and represented ENaC-dependent $\mathrm{Na}^{+}$absorption $\left(n=8-9,{ }^{* *} p<0.05\right)$.

In order to test the viability of colonic tissue in Ussing chambers $6 \mathrm{~h}$ after aldosterone stimulation, we determined changes in $\mathrm{I}_{\mathrm{SC}}\left(\Delta \mathrm{I}_{\mathrm{SC}}, \mu \mathrm{A} / \mathrm{cm}^{2}\right)$ after stimulation of electrogenic $\mathrm{Cl}^{-}$secretion by prostaglandin $\mathrm{E}_{2}$ (PGE2) and theophylline, and its subsequent inhibition by bumetanide. As shown in Table 1, in all mucosae $\mathrm{Cl}^{-}$secretion was stimulated by PGE2 and theophylline and inhibited by bumetanide. No significant differences in $\Delta \mathrm{I}_{\mathrm{SC}}$ were observed between controls and $C$. concisus-infected IL-10 $10^{-/-}$mice, indicating that mucosal viability was maintained (Table 1 ). Furthermore, impedance measurements indicated that there were no differences in epithelial resistance $\left(\mathrm{R}^{\mathrm{epi}}\right)$ and subepithelial resistance $\left(R^{\text {sub }}\right)$ between the two groups (Table 1), which implies that colonic ENaC dysfunction induced by $C$. concisus in IL-10-/- mice was independent of epithelial barrier changes (e.g., leaks or tissue destruction).

Table 1. Evaluation of colonic viability.

\begin{tabular}{|c|c|c|c|c|c|}
\hline \multirow{2}{*}{$\begin{array}{c}\text { Abiotic IL-10-/- } \\
\text { Mice }\end{array}$} & \multirow{2}{*}{$\begin{array}{c}\Delta \mathrm{I}_{\mathrm{SC}}\left(\mu \mathrm{A} / \mathrm{cm}^{2}\right) \text { after } \\
\text { PGE2 + Theophylline }\end{array}$} & \multirow{2}{*}{$\begin{array}{c}\Delta \mathrm{I}_{\mathrm{SC}}\left(\mu \mathrm{A} / \mathrm{cm}^{2}\right) \\
\text { after Bumetanide }\end{array}$} & \multicolumn{3}{|c|}{ Resistance } \\
\hline & & & $\mathbf{R}^{\text {epi }}$ & $\mathbf{R}^{\text {sub }}$ & $\mathbf{R}^{\text {total }}$ \\
\hline Control $(n=4-8)$ & $27 \pm 7.99$ & $-15 \pm 4.08$ & $28.4 \pm 3.62$ & $24.8 \pm 2.15$ & $52.4 \pm 3.55$ \\
\hline $\begin{array}{l}\text { C. concisus-infection } \\
\qquad(n=5-8)\end{array}$ & $25 \pm 8.12$ & $-16 \pm 5.57$ & $33.2 \pm 3.10$ & $28.5 \pm 2.57$ & $61.7 \pm 3.90$ \\
\hline Significance & ns & ns & ns & ns & ns \\
\hline
\end{tabular}

ns, not significant; PGE2, prostaglandin $\mathrm{E}_{2} ; \mathrm{R}^{\text {total }}$, total transepithelial resistance; $\mathrm{R}^{\text {sub }}$, subepithelial resistance; $\mathrm{R}^{\mathrm{epi}}$, epithelial resistance. Data represent the mean $\pm \mathrm{SEM}(p>0.05, \mathrm{~ns})$. No significant difference in correction factors $\left(\mathrm{R}^{\mathrm{total}} / \mathrm{R}^{\mathrm{epi}}\right)$ for active transport rates (i.e., $\left.\mathrm{I}_{\mathrm{SC}}\right)$ were observed between controls and C. concisus-infected mice [controls $=1.99 \pm 0.18$ and C. concisus $=1.91 \pm 0.10, n=8, p>0.05, \mathrm{~ns}$ ].

\section{Discussion}

The first main finding was that C. concisus infection impaired ENaC activity in colonic epithelial cells, which was reflected by a decrease in amiloride-sensitive ISC and the transcriptional down-regulation of $\beta$ - and $\gamma$-ENaC subunits in our HT-29/B6-GR/MR (HT-29/B6 colonic epithelial cells stably transfected with glucocorticoid receptors (GR) and mineralocorticoid receptors (MR)) cell model in vitro. The HT-29/B6-GR/MR epithelial cell model is the only steroid hormone-sensitive intestinal cell model available. Basic glucocorticoids levels like $50 \mathrm{nM}$ dexamethasone in the present study are necessary for a localization of the de novo expressed ENaC subunits in the apical enterocyte cell 
membrane. Butyrate inhibits histone deacetylation and thereby intensify $\beta$ - and $\gamma$-ENaC subunit expression via increased binding of the transcription factor SP3 and histone acetylation [29]. Put together, the HT-29/B6-GR/MR epithelial cell model also allowed us to investigate the intracellular cell signaling pathways that regulate or impair $\mathrm{ENaC}$ function.

During diarrheal states, ENaC-mediated electrogenic sodium absorption is activated in the distal colon as a reserve absorption system to minimize the loss of $\mathrm{Na}^{+}$. C. concisus impaired ENaC-mediated $\mathrm{Na}^{+}$absorption in this cell model. ENaC dysfunction has been identified as a pathomechanism that reduces the overall transport capacity for $\mathrm{Na}^{+}$and directly contributes to $\mathrm{Na}^{+}$malabsorption and watery diarrhea, a predominant intestinal symptom in C. concisus infection [8]. Furthermore, C. concisus was frequently detected in fecal samples of diarrheal patients $[4,5]$. Interestingly, C. concisus is the main non-zoonotic Campylobacter species identified so far in human specimens and a source of infection is yet to be identified in the environment or animals. Indeed, for many years it was unclear whether colonization of $C$. concisus in the human intestinal mucosa is cause or consequence of intestinal inflammation. Nielsen and co-workers demonstrated that $C$. concisus induced barrier dysfunction by epithelial apoptosis and moderate TJ changes in HT-29/B6 cells [9]. The study also supported the pathogenetic principle of a paracellular leak-flux mechanism exhibited by $C$. concisus to induce diarrhea. However, a clinical epidemiological observation found that $C$. concisus-infected patients present prolonged watery diarrhea with the milder intestinal inflammatory outcome and less fever compared to C. jejuni-infected patients [8]. The symptom of watery diarrhea correlates with our experimental finding that $C$. concisus impairs ENaC-dependent sodium absorption in the distal colon leading to watery rather than bloody diarrhea which is frequently induced by other cytotoxic enteropathogens. This feature of $C$. concisus infection was also reflected by our experimental findings of unchanged cell viability with retention of active $\mathrm{Cl}^{-}$secretion, defined TJ changes with claudin-8 dysregulation, and no induction of lesions or cytotoxic destruction of the tissue after $C$. concisus infection.

As the second main result, we showed that $C$. concisus induced ERK activation in HT-29/B6-GR/MR cell monolayers. In the corresponding blockade experiment, ERK inhibition with U0126 ameliorated $\mathrm{ENaC}$ dysfunction after $C$. concisus infection, which is direct evidence that $C$. concisus infection impaired $\mathrm{ENaC}$ function via ERK activation. This means the bacteria not only caused general cell damage, but they also decreased ENaC function via ERK activation. Moreover, a reduction in the mRNA expression of regulatory $\mathrm{ENaC}$ subunits $(-\beta$ and $-\gamma) 48 \mathrm{~h}$ after $C$. concisus infection (Figure 3 ) indicated that C. concisus dysregulates ENaC function. Similar mechanisms of functional ENaC dysregulation were previously reported in Crohn's disease and ulcerative colitis as well as for lymphocytic colitis [18-20].

Tumor necrosis factor (TNF)- $\alpha$ was identified as an important pro-inflammatory cytokine that could down-regulate colonic ENaC expression in different studies $[18,30]$. C. concisus also induced the release of pro-inflammatory cytokines such as interleukin- 8 and TNF- $\alpha$ from intestinal epithelial cells, macrophages and/or THP1 immune cells [31]. Hence, we presumed that TNF $\alpha$-mediated ERK activation might contribute to $\mathrm{ENaC}$ dysfunction in C. concisus infection, as previously demonstrated for Crohn's disease [19] and lymphocytic colitis [20]. However, our RNA-Seq analysis indicated that IL-32 is the cytokine with the highest mRNA expression change rather than TNF- $\alpha$ in C. concisus infection. The bioinformatics prediction through Ingenuity Pathway Analysis (IPA) from our RNA-Seq data indicated that $C$. concisus could promote ERK activation via IL-32, which might lead to ENaC dysfunction in TNF- $\alpha$-independent pathway (scheme, Figure 11). IL-32 has been reported to induce activation of ERK in fibroblast-like synoviocytes in rheumatoid arthritis [32] and human calcified aortic valves [33].

Interestingly, IL-32 can also be activated by interferon- $\gamma$ (IFN- $\gamma$ ) and interleukin-1 $\beta$ (IL-1 $\beta$ ) or through bacterial lipopolysaccharides (LPS) according to our Ingenuity Pathway Analysis (IPA) analysis (Supplementary Table S3). Thus, it may be reasonable to conclude that in the presence of the sub-epithelial immune compartment, cytokines like IFN- $\gamma$ and IL- $1 \beta$ released in response to $C$. concisus infection could intensify the ENaC dysfunction observed in the HT-29/B6-GR/MR cell model in our present study. 


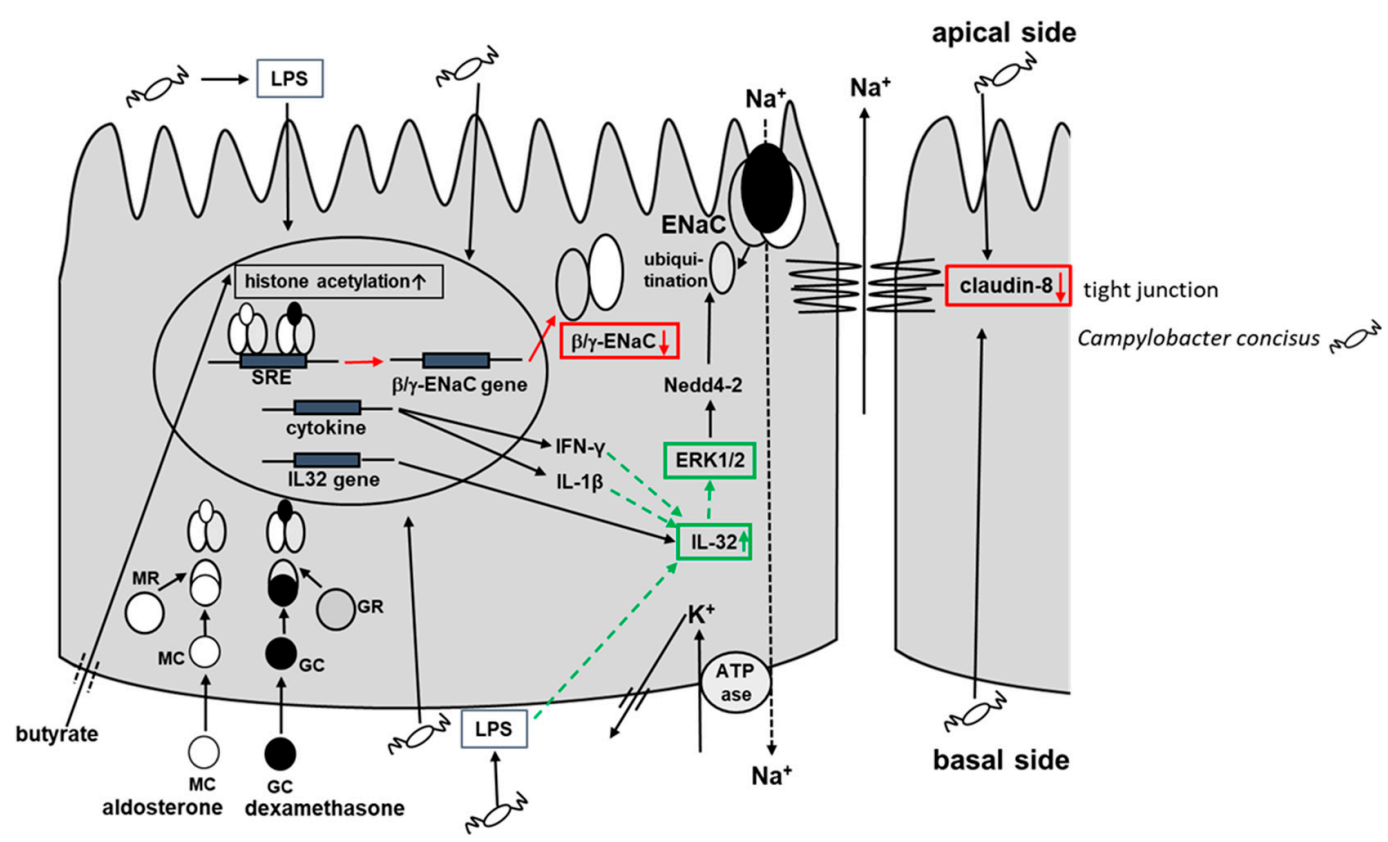

Figure 11. Scheme of Campylobacter concisus-induced impairment of ENaC-dependent $\mathrm{Na}^{+}$absorption in colonic epithelial cells. In diarrheal state, glucocorticoid and mineralocorticoid receptors (GR and MR) are activated by glucocorticoids (GC) like dexamethasone and mineralocorticoids (MC) like aldosterone respectively. GR and MR forms a heterodimer, binds to steroid-responsive element (SRE) and activates the expression of $\beta / \gamma \mathrm{ENaC}$ genes with the subsequent protein synthesis to enhance the electrogenic $\mathrm{Na}^{+}$absorption. Butyrate inhibits histone deacetylation to intensify the expression of $\beta / \gamma \mathrm{ENaC}$ genes. GC (dexamethasone), MC (aldosterone) and butyrate were the activators of ENaC used in our experimental setup [17]. From the findings of our study, the red arrows in the figure represent $C$. concisus-induced transcriptional down-regulation or dysregulation of protein synthesis. The green arrows in the figure represent the transcriptional up-regulation and activation of signaling pathways (ERK pathway) by C. concisus. C. concisus promoted the transcriptional up-regulation of interleukin-32 (IL-32), which might increase its protein expression (indicated by upward green arrow) and lead to activation of neural precursor cell expressed developmentally down-regulated protein (NEED4-2)-dependent ubiquitination of ENaC (via ERK) and impair ENaC-dependent $\mathrm{Na}^{+}$absorption. The dotted green lines represent the predicted activation of IL-32 by upstream regulators IFN- $\gamma$, IL-1 $\beta$ and bacterial LPS (lipopolysaccharides), which could contribute to ERK activation leading to ENaC dysfunction in DBA-stimulated controls $48 \mathrm{~h}$ after $C$. concisus infection (bioinformatics prediction from RNA-Seq data by Ingenuity Pathway Analysis (IPA) software). The mRNA expression of NEED4-2 in the HT-29/B6-GR/MR cell model is confirmed through RNA-Seq data. However, the regulation of NEDD4-2 via ERK1/2 and ubiquitination of ENaC which might lead to disassembly of ENaC subunits from epithelium is also a prediction through IPA. The reduction in claudin-8 protein expression by C. concisus is indicated by red color. The reduction in claudin-8 expression and protein redistribution perturbs the ionic paracellular barrier and leads to back leakage of $\mathrm{Na}^{+}$into the apical side, contributing to the net loss of $\mathrm{Na}^{+}$.

We used amiloride, which selectively inhibited apical ENaC-mediated $\mathrm{Na}^{+}$entry. In parallel with the initial aldosterone-dependent and $\mathrm{ENaC}$-mediated increase and the subsequent amiloridedependent inhibition of $\mathrm{Na}^{+}$absorption, an initial decrease and subsequent amiloride-induced increase in TER were observed. These changes in TER simply reflect the opening and closure of the ENaC and do not give any information on the effect of $C$. concisus infection on the paracellular barrier function. However, the overall TER after amiloride directly reflects the integrity of the paracellular barrier in HT-29/B6-GR/MR cell monolayer. Thus, a direct comparison becomes possible between infected and control monolayers. In this context, TJ protein claudin-8 plays a crucial role as it seals the paracellular space, in order to prevent the back leakage of $\mathrm{Na}^{+}$into the apical compartment [25]. 
The third important finding of our study shows that $C$. concisus-induced $\mathrm{Na}^{+}$malabsorption is accompanied by a decrease in TER, mediated by a reduction in the mRNA and protein expression of claudin-8. This might point to a paracellular barrier dysfunction promoted by C. concisus either as a parallel or as a subsequent effect to ENaC dysfunction. Moreover, a redistribution of claudin-8 from the TJ domain of the cells to intracellular compartments was observed after $C$. concisus infection. Hence, we could confirm that $C$. concisus impairs $\mathrm{Na}^{+}$absorption in colonocytes not only by $\mathrm{ENaC}$ dysfunction but also by claudin-8 disruption, leading to a loss of $\mathrm{Na}^{+}$via the paracellular pathway (scheme, Figure 11). A possible explanation for the proposed paracellular barrier dysfunction promoted by C. concisus, comes from one of our previous studies on claudin-8 regulation in response to $\mathrm{ENaC}$ activity [25], which revealed that $\mathrm{ENaC}$ stimulation also induces claudin-8 expression. Hence, we could ascertain that functional $\mathrm{ENaC}$ impairment by $\mathrm{C}$. concisus could contribute to claudin- 8 expression changes and might contribute to paracellular barrier dysfunction.

Previously, claudin-8 down-regulation was determined in C. jejuni infection in the human colon mucosa. However, this had not been linked with $\mathrm{Na}^{+}$malabsorption and was rather discussed in the context of a general pro-inflammatory barrier dysfunction [26]. From the findings of our present study on C. concisus, a specific contribution of claudin-8 to the loss of $\mathrm{Na}^{+}$seems much more likely. Very few claudins exist with paracellular channel function, like claudin- 2 and -15 which are predominantly expressed in proximal intestinal segments like the jejunum. Other claudins like claudin-8 have rather sealing functions. Together with the expression of distinct transport proteins in the plasma membrane of the enterocytes, TJ proteins define the properties of a specific intestinal segment to be leaky or tight. Thus, a co-regulation of specific claudins and the corresponding channels is predictable but not yet shown. The signaling connection between MAPK and claudin-8 was shown in Yersinia enterocolitica infection and JNK [34] and colorectal cancer and ERK [35]. From this, we can hypothesize that the $\mathrm{ENaC}$ and claudin-8 co-regulation could happen via ERK/MAPK in Campylobacter infection. However, this should be confirmed only after a detailed investigation.

In our present study, a similar pathomechanism was seen after $C$. concisus infection as previously described in lymphocytic colitis, in which claudin-8 disruption and $\mathrm{ENaC}$ dysfunction synergistically promote watery diarrhea $[19,36]$. Interestingly, a clinical study found that $12 \%$ of $C$. concisus-infected patients with prolonged diarrhea developed microscopic colitis (lymphocytic colitis is a subtype of microscopic colitis) in a six-month follow-up period [37]. We also observed a significant increase in the expression of the TJ protein occludin in HT-29/B6-GR/MR cell monolayers after infection with C. concisus. This could be a result of host cell autophagy modulation required for intracellular survival of $C$. concisus $[38,39]$. Besides, occludin was demonstrated not to affect the ionic barrier properties of intestinal epithelia in an occludin knockout mouse model, since the transepithelial electrical resistance did not differ between occludin-deficient mice and their wild-type littermates $[40,41]$. Hence, the increase in occludin expression has to be interpreted as an independent phenomenon regardless of the paracellular barrier change induced by C. concisus.

In order to confirm the effects of $C$. concisus on ENaC function in vivo, we employed the abiotic IL-10 $0^{-/-}$mouse model. Mice display a strong physiological colonization resistance of the intestine due to the mouse-specific gut microbiota composition and are therefore protected from infection with enteropathogens including $C$. jejuni $[42,43]$. Furthermore, mice are per se approximately 10,000-fold more resistant to LOS and lipopolysaccharide (LPS), the major cell wall constituents of C. jejuni or other Gram-negative bacteria $[44,45]$ as compared to humans [46]. It was recently shown that the abiotic IL-10-/- mice (gut microbiota depleted by broad-spectrum antibiotic treatment) are effectively colonized by C. jejuni upon peroral infection and develop key features of acute human Campylobacteriosis [27]. The main reasons for these severe C. jejuni-induced immunopathological responses in the acute stages of enterocolitis in mice are (i) the absence of colonization resistance following microbiota depletion and (ii) the lack of IL-10 enhancing susceptibility of mice to C. jejuni LOS $[27,47]$. In consequence, abiotic IL-10 ${ }^{-/-}$mice infected with C. jejuni display a pronounced LOS-induced and Toll-like receptor (TLR)-4-dependent innate and adaptive immune response in the intestine [27]. Since then, abiotic IL-10 ${ }^{-/-}$mouse model has been successfully employed in many 
studies [48-51]. In recent studies, the abiotic IL-10-/- mouse model was also used to determine the barrier protective and anti-inflammatory effects on $C$. jejuni infection using curcumin or vitamin $\mathrm{D}[52,53]$.

The first experimental infection of mice by $C$. concisus to study inflammatory effects on the intestine was carried out in Bagg Albino/c (BALB/c) mice [54]. However, this study reported poor colonization of $C$. concisus in the intestine of BALB/c mice without any substantial inflammation and proposed an improved mouse model from a different mouse strain for future investigations. In the current study, we achieved successful bacterial colonization of the colon in C. concisus-infected abiotic IL-10 $10^{-/}$mice (C57BL/6 strain). Further, in concordance to our in vitro model, a decrease in ENaC-dependent $\mathrm{Na}^{+}$ transport could be measured in the colon of $C$. concisus-infected IL-10 $0^{-/-}$mice 6 days post-infection. This gives us a solid piece of evidence for $\mathrm{C}$. concisus-induced $\mathrm{ENaC}$ dysfunction in vivo. However, we have not observed any differences in $\mathrm{R}^{\mathrm{epi}}$ and $\mathrm{R}^{\mathrm{sub}}$ values between the colon mucosa of controls and C. concisus-infected mice. This indicates that $C$. concisus neither induces massive inflammation nor impairs epithelial barrier function in the colon but can still cause $\mathrm{ENaC}$ dysfunction.

Taken together, C. concisus impairs ENaC-dependent $\mathrm{Na}^{+}$absorption via down-regulation of $\beta$ - and $\gamma$-ENaC mRNA expression and ERK activation. The mRNA expression of pro-inflammatory cytokine IL-32 is up-regulated after $C$. concisus infection, which might contribute to ERK activation, in turn leading to ENaC dysfunction. In parallel, C. concisus disrupts claudin-8 and facilitates back leakage of $\mathrm{Na}^{+}$ions. Thus, C. concisus induces ENaC dysfunction via ERK activation and claudin-8-dependent barrier dysfunction— both of which contribute to $\mathrm{Na}^{+}$malabsorption and diarrhea.

\section{Materials and Methods}

\subsection{Cell Culture and Campylobacter Infection}

HT-29/B6-GR/MR cell monolayers (epithelial cell line HT-29/B6 transfected with glucocorticoid and mineralocorticoid receptors; [15]) were used to determine functional ENaC activity in vitro. Fresh HT-29/B6-GR/MR cells were cultured in Roswell Park Memorial Institute (RPMI) medium (Sigma Aldrich, St. Louis, MO, USA) for one week at $37^{\circ} \mathrm{C}$ in humidified atmosphere $(95 \%$ air $/ 5 \%$ $\mathrm{CO}_{2}$ ). RPMI media were supplemented with $10 \%$ fetal calf serum (FCS; Gibco, Carlsbad, CA, USA), $1 \%$ penicillin/streptomycin (Gibco, Carlsbad, CA, USA), $500 \mathrm{IU} / \mathrm{mL}$ G418 (Merck Millipore, Billerica, MA, USA) and $200 \mu \mathrm{g} / \mathrm{mL}$ hygromycin B (Biochrom $\mathrm{GmbH}$, Berlin, Germany). After one week, trypsinized cells were seeded on Millicell PCF filters of $3 \mu \mathrm{m}$ pore size (Merck Millipore, Billerica, MA, USA) and cultured for 7-10 days. Experiments were performed when cell monolayers reached a transepithelial electrical resistance (TER) of $1500-2100 \Omega \cdot \mathrm{cm}^{2}$. Cells were incubated with $10 \%$ hormone-free FCS (h-f FCS; Sigma-Aldrich, St. Louis, MO, USA) for $24 \mathrm{~h}$ and stimulated with DBA (a combination of dexamethasone (D, $50 \mathrm{nM}$; Sigma-Aldrich, St. Louis, MO, USA), $\mathrm{Na}^{+}$butyrate (B, 2 mM; Merck-Schuchardt, Hohenbrunn, Germany) and aldosterone (A, $3 \mathrm{nM}$; Sigma-Aldrich, St. Louis, MO, USA)) for four days.

Three days after DBA stimulation, cell monolayers were washed and incubated with heat-inactivated $10 \%$ h-f FCS without any antibiotic supplements for $24 \mathrm{~h}$. Four days post-DBA stimulation, TER values were recorded with chop-stick electrodes and cell monolayers were infected with C. concisus (C. concisus AAuH 37 UC oral [55]) or C. jejuni (C. jejuni wild-type strain 81-176) on both apical and basolateral sides of the cell monolayers at a multiplicity of infection (MOI) of 400 (Figure 12). After infection, cell monolayers were incubated in a $\mathrm{H}_{2}$-containing atmospheric condition [microaerophilic/ $\mathrm{CO}_{2}$-enriched gas pack (BD GasPak EZ CampyPak container system sachets, BD Biosciences, San Jose, CA, USA) and $10 \%$ hydrogen gas $0.082 \mathrm{~g}$ of sodium borohydride $\left(\mathrm{NaBH}_{4}\right)$ in $10 \mathrm{~mL}$ of distilled water in $2.5 \mathrm{~L}$ airtight plastic jar] at $37^{\circ} \mathrm{C}$ for approximately $30 \mathrm{~h}$. Cell monolayers were then placed in a humidified atmosphere at $37^{\circ} \mathrm{C}$. Forty-eight hours post-infection, cell monolayers were used for amiloride-sensitive short circuit current $\left(\mathrm{I}_{\mathrm{SC}}\right)$ measurements in Ussing chambers, total RNA isolation, Western blot analysis, confocal laser-scanning microscopy (CLSM, Zeiss LSM 780, Jena, Germany) and CCK-8 assay. 


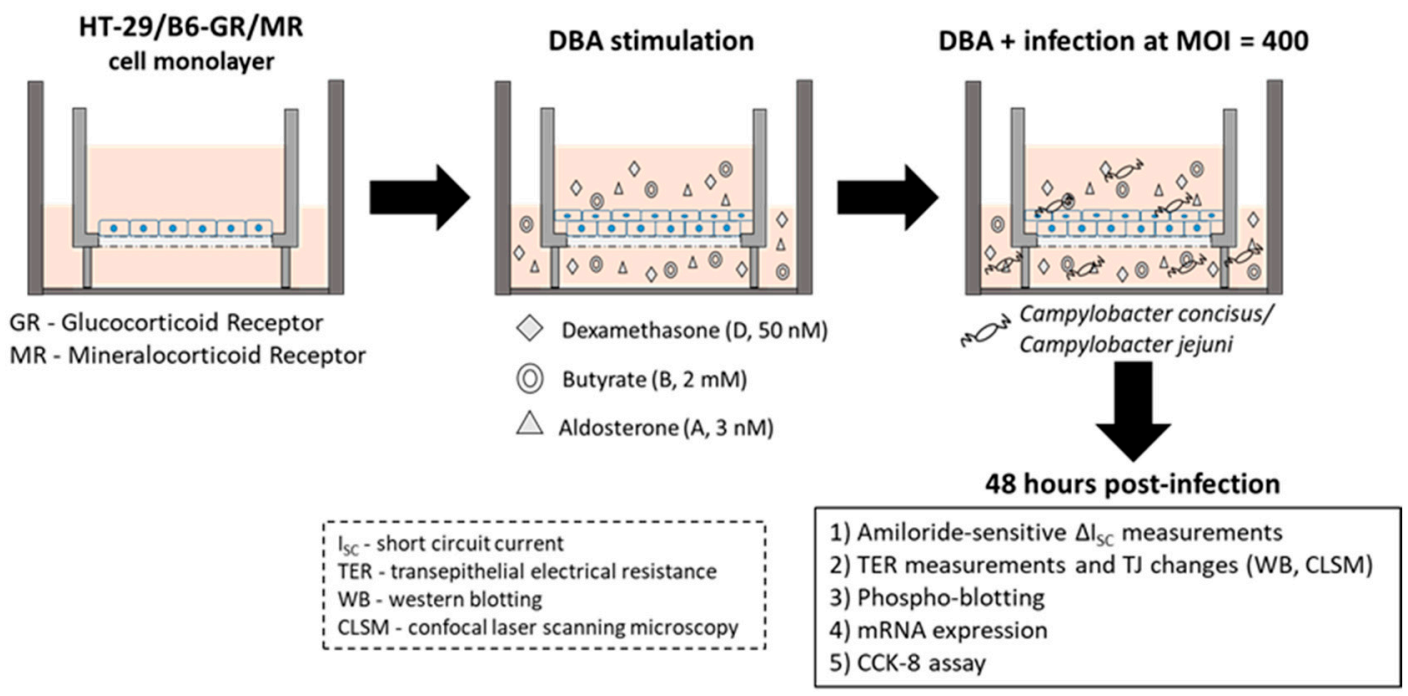

Figure 12. Study design to determine ENaC activity and tight junctional changes after Campylobacter concisus or Campylobacter jejuni infections using the HT-29/B6-GR/MR in vitro cell model.

\subsection{Electrophysiological Determination of ENaC Function In Vitro}

Forty-eight hours post-infection with Campylobacter spp., HT-29/B6-GR/MR cell monolayers grown on filters were mounted in Ussing chambers (epithelial surface area of $0.6 \mathrm{~cm}^{2}$; Institute of Clinical Physiology, Charité, Berlin). The composition of the bathing solution in the Ussing chambers was as follows: $\mathrm{Na}^{+} 140.0 \mathrm{mM} ; \mathrm{Cl}^{-} 123.8 \mathrm{mM} ; \mathrm{K}^{+} 5.4 \mathrm{mM} ; \mathrm{Ca}^{2+} 1.2 \mathrm{mM} ; \mathrm{Mg}^{2+} 1.2 \mathrm{mM} ; \mathrm{HPO}_{4}{ }^{2-} 2.4 \mathrm{mM}$; $\mathrm{H}_{2} \mathrm{PO}_{4}{ }^{-} 0.6 \mathrm{mM}$ and $\mathrm{HCO}^{3-} 21.0 \mathrm{mM}$. The solution was gassed with carbogen gas $\left(95 \% \mathrm{O}_{2}\right.$ and $5 \%$ $\left.\mathrm{CO}_{2}\right)$ by bubble lift. Temperature was maintained at $37^{\circ} \mathrm{C}, \mathrm{pH} 7.4$. TER $\left(\Omega \cdot \mathrm{cm}^{2}\right)$ and short circuit current $\left(\mathrm{I}_{\mathrm{SC}} ; \mu \mathrm{A} / \mathrm{cm}^{2}\right)$ were recorded using voltage clamp devices (CVC6, Fiebig Hard \& Software, Berlin, Germany). Cell monolayers were allowed to stabilize and $\mathrm{ENaC}$-dependent $\mathrm{Na}^{+}$transport recorded as a decrease in $\mathrm{I}_{\mathrm{SC}}\left(\Delta \mathrm{I}_{\mathrm{SC}} ; \mu \mathrm{A} / \mathrm{cm}^{2}\right) 20 \mathrm{~min}$ after the apical addition of the ENaC blocker amiloride (100 $\mu \mathrm{M}$; Sigma-Aldrich, St. Louis, MO, USA). For the complete inhibition of ENaC in the colonic epithelium and mucous-producing HT-29/B6-GR/MR cells, which is covered by a mucous layer, an amiloride concentration of $100 \mu \mathrm{M}$ was employed. This concentration is ten-fold higher than concentrations usually used to completely block the ENaC in kidney cell models $(10 \mu \mathrm{M})$, but still specific for $\mathrm{Na}^{+}$transport via the ENaC, as NHE3, the other transport system for $\mathrm{Na}^{+}$in the apical cell membrane of colonocytes, is only affected by amiloride concentrations at $1 \mathrm{mM}$ [17]. To ensure that epithelial cells were functionally viable during $\Delta \mathrm{I}_{\mathrm{SC}}$ measurements, electrogenic chloride $\mathrm{Cl}^{-}$secretion by the cells was determined by measuring the increase in ISC at end of each experiment in response to the addition of theophylline $(10 \mathrm{mM})$ and PGE2 $(10 \mu \mathrm{M})$, or carbachol $(100 \mu \mathrm{M})$.

\subsection{Western Blot Assessment of Tight Junction Protein Expression}

Forty-eight hours post-infection, TERs of cell monolayers were recorded $20 \mathrm{~min}$ after measuring the amiloride-induced changes in ISC. Cell monolayers of HT-29/B6-GR/MR were then prepared prior to evaluating changes in TJ protein expression. Control and infected cells were scraped carefully from the cell monolayers and subjected to total cell lysis using a lysis buffer $(150 \mathrm{mM} \mathrm{NaCl}, 10 \mathrm{mM}$ Tris buffer $\mathrm{pH}$ of $7.5,0.5 \%$ Triton $\mathrm{X}-100$, and $1 \%$ SDS). The concentration of the proteins isolated was estimated by the Pierce bicinchoninic acid (BCA) assay (Thermo Scientific, Waltham, MA, USA) according to manufacturer's instruction. Proteins were resolved using 12.5\% SDS-PAGE gel, and $15 \mu \mathrm{g}$ of proteins were used from each sample. The resolved proteins were electro-transferred to PVDF nitrocellulose membranes (Thermo Scientific, Waltham, MA, USA) using the Trans-Blot system (Bio-Rad Laboratories, Inc., Hercules, CA, USA) at $25 \mathrm{~V}$ for 15-17 min. 
PVDF membranes were subjected to incubation, shaking with a blocking solution containing $1 \%$ polyvinylpyrrolidone (PVP-40; Sigma Aldrich, St. Louis, MO, USA) in tris-buffered saline (TBS) supplemented with $0.05 \%$ Tween-20 buffer at room temperature (RT) for $2 \mathrm{~h}$ to avoid unspecific protein signals. Membranes were incubated with primary antibodies rabbit $(\mathrm{Rb})$ anti-claudin-1, -2 , -5, -8 (Invitrogen, Carlsbad, CA, USA), Rb anti-occludin (Sigma Aldrich, St. Louis, MO, USA), Rb anti-tricellulin (Invitrogen, Carlsbad, CA, USA), mouse (M) anti- $\beta$-actin (Sigma Aldrich, St. Louis, $\mathrm{MO}, \mathrm{USA}$ ), $\mathrm{M}$ anti-GAPDH (Merck KGaA, Darmstadt, Germany) overnight at $4{ }^{\circ} \mathrm{C}$. Membranes were then incubated with appropriate secondary antibodies (peroxidase-conjugated goat anti-Rb and goat anti-M, Jackson ImmunoResearch, Ely, UK) at RT for $2 \mathrm{~h}$. Membranes were evaluated for bands of specific protein with a chemiluminescence solution (Thermo Scientific, Waltham, MA, USA) using the FUSION FX7 system (Vilber Lourmat Deutschland GmbH, Eberhardzell, Germany). Protein bands were quantified by ImageJ software (Rasband, W. S., ImageJ, National Institute of Health (NIH), Bethesda, MD, USA). Densitometric analysis of the Western blots was performed by normalizing the band intensity of TJ proteins to their respective $\beta$-actin or GAPDH band intensities.

\subsection{Western Blot Assessment of ERK Phosphorylation}

Forty-eight hours post-infection, HT-29/B6-GR/MR cell monolayers were washed and incubated with RPMI media lacking h-f FCS and supplemented with $2 \mathrm{mg} / \mathrm{mL}$ gentamycin (Gibco, Carlsbad, CA, USA) for $3 \mathrm{~h}$ to remove and kill all residual bacteria on the apical and basal sides of the cell monolayers. Cell monolayers were then washed with heat-inactivated $10 \%$ h-f FCS to completely remove gentamycin, after which cells were DBA stimulated and re-infected with $C$. concisus or $C$. jejuni for 5, 15, 30, 60 and 120 min before detecting protein phosphorylation by Western blotting. Cells were scraped carefully from control and the infected monolayers, and removed using complete cell lysis buffer ( $\mathrm{pH}$ 7.5) supplemented with phosphatase inhibitors ( $20 \mathrm{mM}$ Tris, $150 \mathrm{mM} \mathrm{NaCl}, 1 \mathrm{mM}$ Triton X-100, $1 \mathrm{mM}$ EDTA, $1 \mathrm{mM}$ PMSF, $2.5 \mathrm{mM} \mathrm{Na}^{+}$pyrophosphate, $1 \mathrm{mM} \beta$-glycerophosphate, $1 \mathrm{mM}$ $\mathrm{Na}^{+}$orthovanadate, $1 \mathrm{mM}$ EGTA, $1 \mu \mathrm{g} / \mathrm{mL}$ leupeptin, complete protease inhibitor cocktail (Roche, Mannheim, Germany)).

Proteins were isolated from lysed cells and their concentrations determined. Proteins were then resolved and electro-transferred to PVDF nitrocellulose membranes (Thermo Scientific, Waltham, MA, USA). PVDF membranes were blocked, incubated with primary and secondary antibodies and evaluated for specific proteins using FUSION FX7, as described in the Section 4.3. Primary antibodies used to determine ERK phosphorylation were Rb anti-p-ERK1/2, Rb anti-ERK1/2 (Cell Signaling Technology Europe B.V., Frankfurt am Main, Germany) and M anti- $\beta$-actin (Sigma Aldrich, St. Louis, MO, USA). Densitometric analysis of Western blots was performed by normalizing band intensities of p-ERK1/2 and ERK1/2 (total ERK1/2) to their respective $\beta$-actin intensities.

\subsection{Functional Blockade of ERK to Determine the Changes in ENaC Function In Vitro}

Upstream MEK inhibitor U0126 (Biogems International, Inc. Westlake Village, CA, USA), which functionally blocks ERK activity, was used to determine the changes in $\mathrm{ENaC}$-dependent $\mathrm{Na}^{+}$transport $\left(\Delta \mathrm{I}_{\mathrm{SC}}\right)$ after $C$. concisus infection in HT-29/B6-GR/MR cells. For this purpose, we used the in vitro infection model as described in Figure 11 and Section 4.1 with few modifications. Four days post-DBA stimulation, the apical and basolateral compartments of the cell monolayers were treated with the functional MEK inhibitor U0126 at a concentration of $10 \mu \mathrm{M}$ supplemented along with heat-inactivated $10 \%$ h-f FCS without any antibiotic supplements. Then, the cell monolayers were incubated at 37 ${ }^{\circ} \mathrm{C}$ in humidified atmosphere $\left(95 \%\right.$ air $\left./ 5 \% \mathrm{CO}_{2}\right)$ for $2 \mathrm{~h}$. Then, the cell monolayers were infected with C. concisus on both apical and basolateral compartment of the cell monolayers at MOI of 400 . Following infection, the cell monolayers were incubated in a special microaerobic atmospheric condition (as described in Section 4.1) but only for approximately $4 \mathrm{~h}$. Then, the cell monolayers were replaced at $37^{\circ} \mathrm{C}$ in humidified atmosphere. Forty-eight hours post-infection, ENaC-dependent $\mathrm{Na}^{+}$transport $\left(\Delta \mathrm{I}_{\mathrm{SC}}\right)$ was determined as described in Section 4.1. 


\subsection{ENaC Regulatory $\beta$ - and $\gamma$-Subunit and Claudin-8 mRNA Expression Analyzed by RT-qPCR}

Total RNA was extracted from HT-29/B6-GR/MR cells using the mirVana ${ }^{\mathrm{TM}}$ miRNA Isolation Kit (Ambion, Life Technologies, Carlsbad, CA, USA). cDNA was synthesized by reverse-transcription PCR using the High-Capacity cDNA Archive Kit (Applied Biosystems, Mannheim, Germany) with oligo(dT) primer. Real-time PCR was performed according to the manufacturer's instructions with an 7500 FAST Real-Time PCR System (Applied Biosystems, Mannheim, Germany) device using the TaqMan ${ }^{\circledR}$ Gene Expression protocol [HS00165722_m1 for human ENaC $\beta$-subunit (SCCN1B), HS00168918_m1 for human ENaC $\gamma$-subunit (SCNN1G), HS00273282_s1 for human claudin-8 (CLDN8)] with FAM ${ }^{\mathrm{TM}}$ dye-labeled primers. GAPDH-cDNA was quantified using VIC ${ }^{\circledR}$ reporter dyes as endogenous control (all Applied Biosystems, Mannheim, Germany). Differential gene expression was determined by the $2^{-\Delta \Delta C T}$ method [56] and represented as fold-induction with respect to controls.

\subsection{Tight Junction Protein Localization Evaluated by Immunofluorescence and Confocal Laser Scanning Microscopy}

TJ protein distribution in HT-29/B6-GR/MR cell monolayers was investigated four days post-DBA stimulation and $48 \mathrm{~h}$ post-infection with Campylobacter spp. Cell monolayers on $3 \mu \mathrm{M}$ PCF filters were fixed using $2 \%$ paraformaldehyde (PFA; Electron Microscopy Sciences, Hatfield, PA, USA) at RT for $20 \mathrm{~min}$. After fixing, cell monolayers were quenched with $25 \mathrm{mM}$ Glycin (Biomol GmBH, Hamburg, Germany), washed twice with phosphate-buffered saline (PBS; with $\mathrm{Ca}^{2+} / \mathrm{Mg}^{2+}$; $\mathrm{pH}$ 7.4; Sigma Aldrich, St. Louis, MO, USA) and permeabilized with 0.5\% Triton X-100 (Sigma Aldrich, St. Louis Missouri, MO, USA) for $7 \mathrm{~min}$ at RT. Permeabilized monolayers were then washed and incubated with a blocking solution ( $1 \%(v / v)$ goat serum, Gibco, Carlsbad, CA, USA; diluted with $\mathrm{Ca}^{2+}$ - and $\mathrm{Mg}^{2+}$-containing PBS) at RT for $30 \mathrm{~min}$. After blocking, cell monolayers were incubated for $45 \mathrm{~min}$ at $37^{\circ} \mathrm{C}$ with the primary antibodies Rb anti-claudin-8 (Thermo Scientific, Waltham, MA, USA) and M anti-human ZO-1 (BD Biosciences, Franklin Lakes, NJ, USA) at their optimal concentrations.

Following this, cell monolayers were washed twice with $1 \%$ goat serum and incubated with secondary antibodies diluted at concentration of 1:400 in blocking solution (goat anti-Rb green, Alexa Fluor Plus $488 \mathrm{~nm}$ and goat anti-M red, Alexa Fluor $594 \mathrm{~nm}$ (Invitrogen Carlsbad, CA, USA)) for $45 \mathrm{~min}$ at $37^{\circ} \mathrm{C}$. After incubation with secondary antibodies, monolayers were stained for nuclei with 4'-6-diamidino-2-phenylindole dihydrochloride (DAPI; Roche AG, Basel, Switzerland) at a dilution of 1:1000 in blocking solution. Monolayers were then washed with blocking solution and $\mathrm{Ca}^{2+}$ - and $\mathrm{Mg}^{2+}$-containing PBS and rinsed briefly with water and absolute ethanol. The cell filters were dried and mounted on glass slides using the mounting solution ProTaq Mount Fluor (Biocyc, Luckenwalde, Germany), and fixed with coverslips. Localization and/or redistribution of TJ protein claudin-8 (co-stained with ZO-1) in control and the infected cell monolayers was determined by confocal laser-scanning microscopy (CLSM, Zeiss LSM 780, Jena, Germany). Individual Z-stacks of the cell monolayers were recorded using the laser scan function.

\subsection{Electrophysiological Determination of ENaC Function in an In Vivo Model of C. concisus Infection}

IL-10 $10^{-/}$mice were used as in vivo model of C. concisus infection. IL-10-/- mice (in C57BL/6j background) were held under specific pathogen-free (SPF) conditions in the animal facilities of the Forschungseinrichtung für Experimentelle Medizin (Charité-Universitätsmedizin Berlin). Mice were transferred to sterile cages and treated for eight weeks with an antibiotic cocktail in the drinking water ad libitum [supplemented with ampicillin/sulbactum ( $1.5 \mathrm{~g} / \mathrm{L})$, ciprofloxacin $(200 \mathrm{mg} / \mathrm{L})$, impenim/cilastatin $(250 \mathrm{mg} / \mathrm{L})$ ] to remove the commensal gut bacteria. Mice were then infected with C. concisus (C. concisus AAuH 37 UC oral; [55]) via oral gavage at $10^{8}$ colony-forming units (CFU) in a volume of $0.3 \mathrm{~mL}$ PBS. Mice infected with commensal E. coli at same CFU were used as controls. Six days after infection, animals were sacrificed by isoflurane inhalation and their colons carefully removed.

The distal parts of the colon were mounted in Ussing chambers and equilibrated with the bathing solution $\left(\mathrm{Na}^{+} 140.0 \mathrm{mM} ; \mathrm{Cl}^{-} 123.8 \mathrm{mM} ; \mathrm{K}^{+} 5.4 \mathrm{mM} ; \mathrm{Ca}^{2+} 1.2 \mathrm{mM} ; \mathrm{Mg}^{2+} 1.2 \mathrm{mM} ; \mathrm{HPO}_{4}{ }^{2-} 2.4 \mathrm{mM}\right.$; 
$\mathrm{H}_{2} \mathrm{PO}_{4}{ }^{-} 0.6 \mathrm{mM}$ and $\mathrm{HCO}^{3-} 21.0 \mathrm{mM}$ ) for approximately $30 \mathrm{~min}$. The solution was gassed with carbogen gas $\left(95 \% \mathrm{O}_{2}\right.$ and $\left.5 \% \mathrm{CO}_{2}\right)$ by bubble lift. Temperature was maintained at $37^{\circ} \mathrm{C}, \mathrm{pH} 7.4$. Transepithelial resistance (TER, $\Omega \cdot \mathrm{cm}^{2}$ ) and short circuit current $\left(\mathrm{I}_{\mathrm{SC}}, \mu \mathrm{A} / \mathrm{cm}^{2}\right)$ were recorded using voltage clamp devices (CVC6, Feibig Hard \& Software, Berlin, Germany). Distal colons were then treated with the mineralocorticoid aldosterone $(3 \mathrm{nM})$ added to both the apical and basolateral compartments of the Ussing chambers to stimulate $\mathrm{ENaC}$ activity. Six hours later, ENaC-dependent $\mathrm{Na}^{+}$transport was determined as the decrease in $\mathrm{ISC}_{\mathrm{SC}} 15 \mathrm{~min}$ after the addition of the ENaC blocker amiloride (100 $\mu \mathrm{M}$; Sigma-Aldrich, St. Louis, MO, USA) to the apical compartment. To confirm viability of the colonic epithelium after $6 \mathrm{~h}$ of aldosterone exposure, the $\mathrm{Cl}^{-}$secretory response of the epithelium was assessed by measuring increases in $\mathrm{I}_{\mathrm{SC}}$ at end of each experiment after the addition of theophylline $(10 \mathrm{mM})$ and prostaglandin $\mathrm{E}_{2}(10 \mu \mathrm{M})$. Subsequently, inhibition of the stimulated $\mathrm{Cl}^{-}$ secretion was assessed by measuring decreases in $\mathrm{I}_{\mathrm{SC}}$ after the addition of bumetanide $(100 \mu \mathrm{M})$ to the basolateral compartment.

In both control and inflamed colon, $\mathrm{I}_{\mathrm{SC}}$ measurements could be influenced to different degrees by the thickness of the subepithelial tissue layers. Thus, in addition to ISC measurements, the total transepithelial resistance $\left(R^{\text {total }}\right)$ and subepithelial resistance $\left(R^{\text {sub }}\right)$ of colonic samples were recorded via one-path impedance spectroscopy, as described previously [57]. Epithelial resistance $\left(R^{\text {epi }}\right)$ was determined by subtracting $R^{\text {sub }}$ from $R^{\text {total }}$. To ensure that changes in Isc accurately reflected changes in active transport, the contributions from subepithelial tissue were taken into account by calculating the ratio $\mathrm{R}^{\mathrm{total}} / \mathrm{R}^{\mathrm{epi}}$, as described previously $[20,26]$.

\subsection{Ethics Statement}

Animal experiments were carried out in the animal facility at the Forschungseinrichtung für Experimentelle Medizin (Charité-Universitätsmedizin Berlin) according to the German animal protection law (approval number G0172/16 (13 October 2016), LaGeSo Berlin).

\subsection{RNA-Seq Expression Analysis}

Total RNA was obtained from HT-29/B6-GR/MR cells using the mirVana ${ }^{\mathrm{TM}}$ miRNA Isolation Kit (Ambion, Life Technologies, Carlsbad, CA, USA). RNA sequencing was performed using the TrueSeq Stranded Total RNA method on a NovaSeq ${ }^{\text {TM }} 6000$ Sequencing System (https://www.illumina.com/) with quality scores of $\geq 80 \%$.

The reads from RNA-Seq were mapped against the human genome GRCh38 release 97 and sorted using the STAR aligner version 2.7.1a in a two-pass mode [58]. First-pass read mapping utilized coordinates from Ensembl annotation release 97 as a framework. Second-pass mapping added splice sites that were found in the first run. Count tables containing gene-read coverages were obtained using the feature Counts function of the Bioconductor package Rsubread [59], with coordinates from aforementioned Ensembl annotation and default parameters.

The Bioconductor package DESeq2 [60] was used to quantify the differential expression of genes between two conditions in form of log2-fold changes with their corresponding $p$-values. $p$-values were adjusted for multiple testing using the Benjamini-Hochberg procedure. Pathway analysis was performed with Ingenuity Pathway Analysis software (IPA, Qiagen Silicon Valley, Redwood, CA, USA) to evaluate the $C$. concisus-dependent changes in the expression of different genes that regulate $\mathrm{ENaC}$ function. Fastq files containing the unprocessed raw reads from sequencing and a raw counts matrix table are publicly available at Gene Expression Omnibus (GEO) archive under National Centre for Biotechnology Information (NCBI) website with GEO accession ID 141217 [Campylobacter concisus impairs sodium absorption via $\mathrm{ENaC}$ dysfunction and claudin-8 disruption. Available online: https://www.ncbi.nlm.nih.gov/gds/?term=GSE141217 (1 January 2020)].

In addition, counts per million and log-transformed counts per million (CPM) normalization was performed using CPM function of the Bioconductor package edgeR [61], and the gene expression of IL-32 was determined using CPM. 


\subsection{Cell Proliferation and Cytotoxicity Assay}

The possibility of cytotoxicity and the cell proliferation rate in HT-29/B6-GR/MR cell monolayers $48 \mathrm{~h}$ after C. concisus infection were evaluated by CCK-8 assay (Cell Counting Kit-8, Thermo Scientific, Waltham, MA, USA). HT-29/B6-GR/MR cells were seeded into 96 well plates and incubated for $7-10$ days at $37^{\circ} \mathrm{C}$ in a humidified atmosphere $\left(95 \%\right.$ air $\left./ 5 \% \mathrm{CO}_{2}\right)$. Cells were stimulated with DBA (a combination of dexamethasone (D, $50 \mathrm{nM}$; Sigma-Aldrich, St. Louis, MO, USA), $\mathrm{Na}^{+}$butyrate (B, 2 mM; Merck-Schuchardt, Hohenbrunn, Germany) and aldosterone (A, $3 \mathrm{nM}$; Sigma-Aldrich, St. Louis, MO, USA)) for four days after an overnight incubation with 10\% hormone-free FCS (h-f FCS; Sigma-Aldrich, St. Louis, MO, USA). Four days post-DBA stimulation, cells in 96 well plates were infected with C. concisus (C. concisus AAuH 37 UC oral; [43]) at a multiplicity of infection (MOI) of 400 . Forty-eight hours post-infection, cell viability was determined by CCK- 8 assay according to manufacturer's instructions. $10 \mu \mathrm{L}$ of CCK-8 solution (WST-8 [2-(2-methoxy-4-nitrophenyl)-5-(2, 4-disulfophenyl)-2H-tetrazolium, monosodium salt]) was added to $100 \mu \mathrm{L}$ of cell suspensions in 96 well plates. WST-8 produced a water-soluble formazan dye (orange colored product) generated by oxidation of cellular dehydrogenases [62,63]. Two hours after addition of the CCK-8 solution to the 96 well plates, absorbance values were recorded using a spectrophotometer (Tecan $\mathrm{GmbH}$, Maennedorf, Switzerland) at $450 \mathrm{~nm}$, with a reference wavelength of $600 \mathrm{~nm}$. Absorbance values represented the amount of formazan dye generated by cellular dehydrogenases and were directly proportional to the number of living cells.

\subsection{Statistical Analysis}

All data are expressed as the mean value \pm standard error of the mean (SEM). Statistical analyses were performed with GraphPad Prism (GraphPad Software version 5.0, Inc., San Diego, CA, USA). For data in Figures 1, 3-7 and 9, the unpaired t-test with Welch's correction for unequal variances was applied. For data that were not normally distributed (Figure 10 and Table 1), the Mann-Whitney $U$-Test was used. To compare data sets from three different samples (data of Figure 2), two-way ANOVA with Bonferroni-Holm adjustment was used. $p<0.05$ was considered statistically significant.

\section{Conclusions}

Campylobacter concisus impairs ENaC-dependent $\mathrm{Na}^{+}$absorption via down-regulation of $\beta$ - and $\gamma$-ENaC mRNA expression and ERK activation. The up-regulated mRNA expression of pro-inflammatory cytokine IL-32 after $C$. concisus infection might contribute to ERK activation, in turn leading to ENaC dysfunction. Besides, C. concisus disrupts claudin-8 and facilitates back leakage of $\mathrm{Na}^{+}$ions. Hence, C. concisus induces ENaC dysfunction via ERK activation and claudin-8-dependent barrier dysfunction-both of which contribute to $\mathrm{Na}^{+}$malabsorption and diarrhea.

Supplementary Materials: The following are available online at http://www.mdpi.com/1422-0067/21/2/373/s1, Figure S1: mRNA expression changes of ENaC subunits $(-\alpha,-\beta,-\gamma)$ in HT-29/B6-GR/MR cells 48 h after Camplyobacter concisus infection; Table S1: Differentially expressed genes in C. concisus infection; Table S2: mRNA expression of different ion-channel transporters after C. concisus infection; Table S3: Upstream regulator analysis.

Author Contributions: Conceptualization, P.K.N., R.B., H.T., and J.-D.S.; Data curation, P.K.N., F.D.L.d.S., A.F., O.N., and E.B.; Formal analysis, P.K.N., F.D.L.d.S., A.F., O.N., I.-F.M.L., E.B., M.M.H., S.B., H.L.N., M.R.S., and H.T.; Funding acquisition, J.-D.S., H.T., and R.B.; Investigation, P.K.N., R.B., F.D.L.d.S., A.F., I.-F.M.L., E.B., S.M., C.G., and S.K.; Methodology, P.K.N., R.B., S.M., C.G., S.K., M.M.H., S.B., M.R.S., H.T., and J.-D.S.; Project administration, J.-D.S., R.B., and H.T.; Resources, H.L.N., and M.R.S.; Supervision, J.-D.S., R.B., and H.T.; M.M.H., and S.B.; Validation, R.B., H.T., and J.-D.S.; Visualization, P.K.N.; Writing-original draft, P.K.N.; Writing-review and editing, R.B., F.D.L.d.S., A.F., O.N., I.-F.M.L., E.B., M.M.H., S.B., H.L.N., M.R.S., H.T., and J.-D.S. All authors have read and agreed to the published version of the manuscript.

Funding: This research was funded by (i) the German Research foundation (DFG, GRK 2318) to J.-D.S., and H.T., (ii) the German Federal Ministries of Education and Research (BMBF, PAC-CAMPY) to R.B. and J.-D.S. (IP8/01KI1725D) and S.B. and M.M.H. (IP7/01KI1725D), (iii) the Volkswagenstiftung (Lichtenberg program) and Center for Molecular Medicine Cologne to M.R.S. and (iv) the Open Access Publication Fund of the Charité-Universitätsmedizin Berlin. 
Acknowledgments: We thank Geoffrey I. Sandle (University of Leeds, Leeds, UK) for his substantial contribution to this study through intellectual support and final editing of the manuscript.

Conflicts of Interest: The authors declare no conflict of interest.

\section{Abbreviations}

\begin{tabular}{|c|c|}
\hline cAMP & Cyclic adenosine monophosphate \\
\hline cDNA & Complementary DNA \\
\hline CFU & Colony forming unit \\
\hline CLSM & Confocal laser scanning microscopy \\
\hline DAPI & 4'-6-diamidino-2-phenylindole dihydrochloride \\
\hline DBA & Dexamethasone, butyrate and aldosterone \\
\hline EDTA & Ethylenediaminetetraacetic acid \\
\hline EGTA & Ethylene glycol-bis( $\beta$-aminoethyl ether)- $N, N, N^{\prime}, N^{\prime}$-tetraacetic acid \\
\hline $\mathrm{ENaC}$ & Epithelial sodium channel \\
\hline ERK & Extracellular signal-regulated kinase \\
\hline FCS & Fetal calf serum \\
\hline GAPDH & Glyceraldehyde 3-phosphate dehydrogenase \\
\hline GC & Glucocorticoids \\
\hline GR & Glucocorticoid receptor \\
\hline $\mathrm{H}_{2} \mathrm{PO}_{4}^{-}$ & Dihydrogen phosphate \\
\hline $\mathrm{HCO}_{3}^{-}$ & Hydrogen carbonate \\
\hline h-f FCS & Hormone-free FCS \\
\hline $\mathrm{HPO}_{4}^{2-}$ & Hydrogen phosphate \\
\hline IFN & Interferon \\
\hline IL & Interleukin \\
\hline $\mathrm{I}_{\mathrm{SC}}$ & Short circuit current \\
\hline JAM & Junctiunal adhesion molecule \\
\hline JNK & c-Jun N-terminal kinase \\
\hline LaGeSo & Landesamt für Gesundheit und Soziales \\
\hline MAPK & Mitogen-activated protein kinase \\
\hline $\mathrm{MC}$ & Mineralocorticoids \\
\hline MEK & Mitogen-activated protein kinase kinase \\
\hline miRNA & MicroRNA \\
\hline MOI & Multiplicity of infection \\
\hline MR & Mineralocorticoid receptor \\
\hline mRNA & Messenger RNA \\
\hline PBS & Phosphate-buffered saline \\
\hline PGE2 & Prostaglandin E2 \\
\hline PMSF & Phenylmethylsulfonyl fluoride \\
\hline PVDF & Polyvinylidene fluoride \\
\hline PVP & Polyvinylpyrrolidone \\
\hline STAT-6 & Signal transducer and activator of transcription 6 \\
\hline TER & Transepithelial electrical resistance \\
\hline $\mathrm{TJ}$ & Tight junction \\
\hline TNF & Tumor necrosis factor \\
\hline
\end{tabular}

\section{References}

1. Tanner, A.C.; Badger, S.; Lai, C.-H.; Listgarten, M.A.; Visconti, R.A.; Socransky, S.S. Wolinella gen. nov., Wolinella succinogenes (Vibrio succinogenes Wolin et al.) comb. nov., and Description of Bacteroides gracilis sp. nov., Wolinella recta sp. nov., Campylobacter concisus sp. nov., and Eikenella corrodens from Humans with Periodontal Disease. Int. J. Syst. Bacteriol. 1981, 31, 432-435.

2. Tanner, A.C.; Dzink, J.L.; Ebersole, J.L.; Socransky, S.S. Wolinella recta, Campylobacter concisus, Bacteroides gracilis, and Eikenella corrodens from periodontal lesions. J. Periodontal Res. 1987, 22, 327-330. [CrossRef] [PubMed] 
3. Macuch, P.J.; Tanner, A.C. Campylobacter species in health, gingivitis, and periodontitis. J. Dent. Res. 2000, 79, 785-792. [CrossRef] [PubMed]

4. Lindblom, G.B.; Sjogren, E.; Hansson-Westerberg, J.; Kaijser, B. Campylobacter upsaliensis, C. Sputorum sputorum and C. Concisus as common causes of diarrhoea in Swedish children. Scand. J. Infect. Dis. 1995, 27, 187-188. [CrossRef]

5. Aabenhus, R.; Permin, H.; On, S.L.; Andersen, L.P. Prevalence of Campylobacter concisus in diarrhoea of immunocompromised patients. Scand. J. Infect. Dis. 2002, 34, 248-252. [CrossRef]

6. Van Etterijck, R.; Breynaert, J.; Revets, H.; Devreker, T.; Vandenplas, Y.; Vandamme, P.; Lauwers, S. Isolation of Campylobacter concisus from feces of children with and without Diarrhea. J. Clin. Microbiol. 1996, 34, 2304-2306. [CrossRef]

7. Maher, M.; Finnegan, C.; Collins, E.; Ward, B.; Carroll, C.; Cormican, M. Evaluation of culture methods and a DNA probe-based PCR assay for detection of campylobacter species in clinical specimens of feces. J. Clin. Microbiol. 2003, 41, 2980-2986. [CrossRef]

8. Nielsen, H.L.; Engberg, J.; Ejlertsen, T.; Bucker, R.; Nielsen, H. Short-term and medium-term clinical outcomes of Campylobacter concisus infection. Clin. Microbiol. Infect. 2012, 18, E459-E465. [CrossRef]

9. Nielsen, H.L.; Nielsen, H.; Ejlertsen, T.; Engberg, J.; Gunzel, D.; Zeitz, M.; Hering, N.A.; Fromm, M.; Schulzke, J.D.; Bucker, R. Oral and fecal Campylobacter concisus strains perturb barrier function by apoptosis induction in HT-29/B6 intestinal epithelial cells. PLoS ONE 2011, 6, e23858. [CrossRef]

10. Schultheis, P.J.; Clarke, L.L.; Meneton, P.; Miller, M.L.; Soleimani, M.; Gawenis, L.R.; Riddle, T.M.; Duffy, J.J.; Doetschman, T.; Wang, T.; et al. Renal and intestinal absorptive defects in mice lacking the $\mathrm{NHE} \mathrm{Na}^{+} / \mathrm{H}^{+}$ exchanger. Nat. Genet. 1998, 19, 282-285. [CrossRef]

11. Canessa, C.M.; Schild, L.; Buell, G.; Thorens, B.; Gautschi, I.; Horisberger, J.D.; Rossier, B.C. Amiloride-sensitive epithelial $\mathrm{Na}^{+}$channel is made of three homologous subunits. Nature 1994, 367, 463-467. [CrossRef] [PubMed]

12. Renard, S.; Voilley, N.; Bassilana, F.; Lazdunski, M.; Barbry, P. Localization and regulation by steroids of the alpha, beta and gamma subunits of the amiloride-sensitive $\mathrm{Na}^{+}$channel in colon, lung and kidney. Pflïg. Arch. 1995, 430, 299-307. [CrossRef] [PubMed]

13. Epple, H.J.; Amasheh, S.; Mankertz, J.; Goltz, M.; Schulzke, J.D.; Fromm, M. Early aldosterone effect in distal colon by transcriptional regulation of ENaC subunits. Am. J. Physiol. Gastrointest. Liver Physiol. 2000, 278, G718-G724. [CrossRef] [PubMed]

14. Greig, E.R.; Baker, E.H.; Mathialahan, T.; Boot-Handford, R.P.; Sandle, G.I. Segmental variability of ENaC subunit expression in rat colon during dietary sodium depletion. Pflüg. Arch. 2002, 444, 476-483.

15. Bergann, T.; Fromm, A.; Borden, S.A.; Fromm, M.; Schulzke, J.D. Glucocorticoid receptor is indispensable for physiological responses to aldosterone in epithelial $\mathrm{Na}^{+}$channel induction via the mineralocorticoid receptor in a human colonic cell line. Eur. J. Cell Biol. 2011, 90, 432-439. [CrossRef] [PubMed]

16. Kuntzsch, D.; Bergann, T.; Dames, P.; Fromm, A.; Fromm, M.; Davis, R.A.; Melzig, M.F.; Schulzke, J.D. The plant-derived glucocorticoid receptor agonist Endiandrin A acts as co-stimulator of colonic epithelial sodium channels (ENaC) via SGK-1 and MAPKs. PLoS ONE 2012, 7, e49426. [CrossRef]

17. Dames, P.; Bergann, T.; Fromm, A.; Bucker, R.; Barmeyer, C.; Krug, S.M.; Fromm, M.; Schulzke, J.D. Interleukin-13 affects the epithelial sodium channel in the intestine by coordinated modulation of stat 6 and p38 MAPK activity. J. Physiol. 2015, 593, 5269-5282. [CrossRef]

18. Amasheh, S.; Barmeyer, C.; Koch, C.S.; Tavalali, S.; Mankertz, J.; Epple, H.J.; Gehring, M.M.; Florian, P.; Kroesen, A.J.; Zeitz, M.; et al. Cytokine-dependent transcriptional down-regulation of epithelial sodium channel in ulcerative colitis. Gastroenterology 2004, 126, 1711-1720. [CrossRef]

19. Zeissig, S.; Bergann, T.; Fromm, A.; Bojarski, C.; Heller, F.; Guenther, U.; Zeitz, M.; Fromm, M.; Schulzke, J.D. Altered $\mathrm{ENaC}$ expression leads to impaired sodium absorption in the noninflamed intestine in Crohn's disease. Gastroenterology 2008, 134, 1436-1447. [CrossRef]

20. Barmeyer, C.; Erko, I.; Fromm, A.; Bojarski, C.; Loddenkemper, C.; Dames, P.; Kerick, M.; Siegmund, B.; Fromm, M.; Schweiger, M.R.; et al. ENaC dysregulation through activation of MEK1/2 contributes to impaired $\mathrm{Na}^{+}$absorption in lymphocytic colitis. Inflamm. Bowel Dis. 2016, 22, 539-547. [CrossRef]

21. Chiba, H.; Osanai, M.; Murata, M.; Kojima, T.; Sawada, N. Transmembrane proteins of tight junctions. Biochim. Biophys. Acta 2008, 1778, 588-600. [CrossRef] [PubMed]

22. Ivanov, A.I. Structure and regulation of intestinal epithelial tight junctions: Current concepts and unanswered questions. Adv. Exp. Med. Biol. 2012, 763, 132-148. [PubMed] 
23. Krug, S.M.; Gunzel, D.; Conrad, M.P.; Lee, I.F.; Amasheh, S.; Fromm, M.; Yu, A.S. Charge-selective claudin channels. Ann. N. Y. Acad. Sci. 2012, 1257, 20-28. [CrossRef] [PubMed]

24. Tamura, A.; Hayashi, H.; Imasato, M.; Yamazaki, Y.; Hagiwara, A.; Wada, M.; Noda, T.; Watanabe, M.; Suzuki, Y.; Tsukita, S. Loss of claudin-15, but not claudin-2, causes $\mathrm{Na}^{+}$deficiency and glucose malabsorption in mouse small intestine. Gastroenterology 2011, 140, 913-923. [CrossRef]

25. Amasheh, S.; Milatz, S.; Krug, S.M.; Bergs, M.; Amasheh, M.; Schulzke, J.D.; Fromm, M. Na ${ }^{+}$absorption defends from paracellular back-leakage by claudin-8 upregulation. Biochem. Biophys. Res. Commun. 2009, 378, 45-50. [CrossRef]

26. Bucker, R.; Krug, S.M.; Moos, V.; Bojarski, C.; Schweiger, M.R.; Kerick, M.; Fromm, A.; Janssen, S.; Fromm, M.; Hering, N.A.; et al. Campylobacter jejuni impairs sodium transport and epithelial barrier function via cytokine release in human colon. Mucosal Immunol. 2018, 11, 474-485. [CrossRef]

27. Haag, L.M.; Fischer, A.; Otto, B.; Plickert, R.; Kuhl, A.A.; Gobel, U.B.; Bereswill, S.; Heimesaat, M.M. Campylobacter jejuni induces acute enterocolitis in gnotobiotic il-10-/- mice via toll-like-receptor-2 and -4 signaling. PLoS ONE 2012, 7, e40761. [CrossRef]

28. Heimesaat, M.M.; Lugert, R.; Fischer, A.; Alutis, M.; Kuhl, A.A.; Zautner, A.E.; Tareen, A.M.; Gobel, U.B.; Bereswill, S. Impact of Campylobacter jejuni cj0268c knockout mutation on intestinal colonization, translocation, and induction of immunopathology in gnotobiotic IL-10 deficient mice. PLoS ONE 2014, 9, e90148. [CrossRef]

29. Zeissig, S.; Fromm, A.; Mankertz, J.; Weiske, J.; Zeitz, M.; Fromm, M.; Schulzke, J.D. Butyrate induces intestinal sodium absorption via sp3-mediated transcriptional up-regulation of epithelial sodium channels. Gastroenterology 2007, 132, 236-248. [CrossRef]

30. Barmeyer, C.; Amasheh, S.; Tavalali, S.; Mankertz, J.; Zeitz, M.; Fromm, M.; Schulzke, J.D. IL-1 $\beta$ and TNF $\alpha$ regulate sodium absorption in rat distal colon. Biochem. Biophys. Res. Commun. 2004, 317, 500-507. [CrossRef]

31. Man, S.M.; Kaakoush, N.O.; Leach, S.T.; Nahidi, L.; Lu, H.K.; Norman, J.; Day, A.S.; Zhang, L.; Mitchell, H.M. Host attachment, invasion, and stimulation of proinflammatory cytokines by Campylobacter concisus and other non-Campylobacter jejuni campylobacter species. J. Infect. Dis. 2010, 202, 1855-1865. [CrossRef] [PubMed]

32. Kim, Y.J.; Lee, C.K.; Kim, S.H.; Cho, W.S.; Mun, S.H.; Yoo, B. Interleukin-32 $\gamma$ Enhances the Production of IL-6 and IL-8 in Fibroblast-Like Synoviocytes Via Erk1/2 Activation. J. Clin. Immunol. 2010, 30, $260-267$. [CrossRef] [PubMed]

33. Tsai, C.L.; Chiu, Y.M.; Lee, Y.J.; Hsieh, C.T.; Shieh, D.C.; Tsay, G.J.; Bau, D.T.; Wu, Y.Y. Interleukin-32 plays an essential role in human calcified aortic valve cells. Eur. Cytokine Netw. 2018, 29, 36-47. [CrossRef] [PubMed]

34. Hering, N.A.; Richter, J.F.; Krug, S.M.; Gunzel, D.; Fromm, A.; Bohn, E.; Rosenthal, R.; Bucker, R.; Fromm, M.; Troeger, H.; et al. Yersinia enterocolitica induces epithelial barrier dysfunction through regional tight junction changes in colonic HT-29/B6 cell monolayers. Lab. Investig. 2011, 91, 310-324. [CrossRef]

35. Cheng, B.; Rong, A.; Zhou, Q.; Li, W. Cldn8 promotes colorectal cancer cell proliferation, migration, and invasion by activating MAPK/Erk signaling. Cancer Manag. Res. 2019, 11, 3741-3751. [CrossRef]

36. Barmeyer, C.; Erko, I.; Awad, K.; Fromm, A.; Bojarski, C.; Meissner, S.; Loddenkemper, C.; Kerick, M.; Siegmund, B.; Fromm, M.; et al. Epithelial barrier dysfunction in lymphocytic colitis through cytokine-dependent internalization of claudin-5 and -8. J. Gastroenterol. 2017, 52, 1090-1100. [CrossRef]

37. Nielsen, H.L.; Engberg, J.; Ejlertsen, T.; Nielsen, H. Evaluation of fecal calprotectin in Campylobacter concisus and Campylobacter jejuni/coli gastroenteritis. Scand. J. Gastroenterol. 2013, 48, 633-635. [CrossRef]

38. Burgos-Portugal, J.A.; Mitchell, H.M.; Castano-Rodriguez, N.; Kaakoush, N.O. The role of autophagy in the intracellular survival of Campylobacter concisus. FEBS Open Bio 2014, 4, 301-309. [CrossRef]

39. Wong, M.; Ganapathy, A.S.; Suchanec, E.; Laidler, L.; Ma, T.; Nighot, P. Intestinal epithelial tight junction barrier regulation by autophagy-related protein atg6/beclin 1. Am. J. Physiol. Cell Physiol. 2019, 316, C753-C765. [CrossRef]

40. Saitou, M.; Furuse, M.; Sasaki, H.; Schulzke, J.D.; Fromm, M.; Takano, H.; Noda, T.; Tsukita, S. Complex phenotype of mice lacking occludin, a component of tight junction strands. Mol. Biol. Cell 2000, 11, 4131-4142. [CrossRef]

41. Schulzke, J.D.; Gitter, A.H.; Mankertz, J.; Spiegel, S.; Seidler, U.; Amasheh, S.; Saitou, M.; Tsukita, S.; Fromm, M. Epithelial transport and barrier function in occludin-deficient mice. Biochim. Biophys. Acta 2005, 1669, 34-42. [CrossRef] 
42. Bereswill, S.; Fischer, A.; Plickert, R.; Haag, L.M.; Otto, B.; Kühl, A.A.; Dashti, J.I.; Zautner, A.E.; Muñoz, M.; Loddenkemper, C.; et al. Novel murine Infection Models Provide Deep Insights into the "Ménage à Trois" of Campylobacter jejuni, Microbiota and Host Innate Immunity. PLoS ONE 2011, 6, e209523. [CrossRef]

43. Masanta, W.O.; Heimesaat, M.M.; Bereswill, S.; Tareen, A.M.; Lugert, R.; Groß, U.; Zautner, A.E. Modification of Intestinal Microbiota and Its Consequences for Innate Immune Response in the Pathogenesis of Campylobacteriosis. Clin. Dev. Immunol. 2013, 526860. [CrossRef] [PubMed]

44. Robertson, S.A.; Care, A.S.; Skinner, R.J. Interleukin 10 Regulates Inflammatory Cytokine Synthesis to Protect Against Lipopolysaccharide-Induced Abortion and Fetal Growth Restriction in Mice. Biol. Reprod. 2007, 76, 738-748. [CrossRef] [PubMed]

45. Warren, H.S.; Fitting, C.; Hiff, E.; Adib-Conquy, M.; Beasley-Topliffe, L.; Tesini, B.; Liang, X.; Valentine, C.; Hellman, J.; Hayden, D.; et al. Resilience to bacterial infection: Difference between species could be due to proteins in serum. J. Infect. Dis. 2010, 201, 223-232. [CrossRef]

46. Taveira da Silva, A.M.; Kaulbach, H.C.; Chuidian, F.S.; Lambert, D.R.; Suffredeni, A.F.; Danner, R.L. Brief Report: Shock and Multiple-Organ Dysfunction after Self-Administration of Salmonella Endotoxin. N. Engl. J. Med. 1993, 328, 1457-1460. [CrossRef]

47. Stahl, M.; Ries, J.; Vermeulen, J.; Yang, H.; Sham, H.P.; Crowley, S.M.; Badayeva, Y.; Turvey, S.E.; Gaynor, E.C.; Li, X.; et al. A Novel Mouse Model of Campylobacter jejuni Gastroenteritis Reveals Key Pro-inflammatory and Tissue Protective Roles for Toll-like Receptor Signaling during Infection. PLoS Pathog. 2014, 10, e1004624. [CrossRef]

48. Haag, L.M.; Fischer, A.; Otto, B.; Plickert, R.; Kühl, A.A.; Göbel, U.B.; Bereseswill, S.; Heimesaat, M.M. Intestinal Microbiota Shift towards Elevated Commensal Escherichia coli Loads Abrogate Colinization Resistance against Campylobacter jejuni in Mice. PLoS ONE 2012, 7, e35988. [CrossRef]

49. Alutis, M.E.; Grundmann, U.; Fischer, A.; Kühl, A.A.; Bereswill, S.; Heimesaat, M.M. Selective Gelatinase Inhibition reduces Apoptosis and Pro-inflammatory Immune Cell Responses in Campylobacter jejuni-infected Gnotobiotic IL-10 Deficient Mice. Eur. J. Microbiol. Immunol. 2014, 4, 213-222. [CrossRef]

50. Heimesaat, M.M.; Grundmann, U.; Alutis, M.E.; Fischer, A.; Bereswill, S. Microbiota Composition and Immune Responses during Campylobacter jejuni Infection in Conventionally Colonized IL-10-/- Mice Lacking Nucleotide Oligomerization Domain 2. Eur. J. Microbiol. Immunol. 2017, 7, 1-14. [CrossRef]

51. Bereswill, S.; Grundmann, U.; Alutis, M.E.; Fischer, A.; Heimesaat, M.M. Immune responses upon Campylobacter jejuni infection of secondary abiotic mice lacking nucleotide-oligomerization-domain- 2 . Gut Pathog. 2017, 9, 33. [CrossRef] [PubMed]

52. Lobo de Sa, F.D.; Butkevych, E.; Nattramilarasu, P.K.; Fromm, A.; Mousavi, S.; Moos, V.; Golz, J.C.; Stingl, K.; Kittler, S.; Seinige, D.; et al. Curcumin mitigates immune-induced epithelial barrier dysfunction by Campylobacter jejuni. Int. J. Mol. Sci. 2019, 20, 4830. [CrossRef] [PubMed]

53. Mousavi, S.; Lobo de Sa, F.D.; Schulzke, J.D.; Bucker, R.; Bereswill, S.; Heimesaat, M.M. Vitamin d in acute campylobacteriosis-results from an intervention study applying a clinical Campylobacter jejuni induced enterocolitis model. Front. Immunol. 2019, 10, 2094. [CrossRef] [PubMed]

54. Aabenhus, R.; Stenram, U.; Andersen, L.P.; Permin, H.; Ljungh, A. First attempt to produce experimental Campylobacter concisus infection in mice. World J. Gastroenterol. 2008, 14, 6954-6959. [CrossRef]

55. Kirk, K.F.; Meric, G.; Nielsen, H.L.; Pascoe, B.; Sheppard, S.K.; Thorlacius-Ussing, O.; Nielsen, H. Molecular epidemiology and comparative genomics of Campylobacter concisus strains from saliva, faeces and gut mucosal biopsies in inflammatory bowel disease. Sci. Rep. 2018, 8, 1902. [CrossRef]

56. Livak, K.J.; Schmittgen, T.D. Analysis of relative gene expression data using real-time quantitative pcr and the 2(-delta delta $\mathrm{c}(\mathrm{t}))$ method. Methods 2001, 25, 402-408. [CrossRef]

57. Schulzke, J.D.; Fromm, M.; Hegel, U. Epithelial and subepithelial resistance of rat large intestine: Segmental differences, effect of stripping, time course, and action of aldosterone. Pflüg. Arch. 1986, 407, 632-637. [CrossRef]

58. Dobin, A.; Davis, C.A.; Schlesinger, F.; Drenkow, J.; Zaleski, C.; Jha, S.; Batut, P.; Chaisson, M.; Gingeras, T.R. Star: Ultrafast universal RNA-seq aligner. Bioinformatics 2013, 29, 15-21. [CrossRef]

59. Liao, Y.; Smyth, G.K.; Shi, W. The R package rsubread is easier, faster, cheaper and better for alignment and quantification of RNA sequencing reads. Nucleic Acids Res. 2019, 47, e47. [CrossRef]

60. Love, M.I.; Huber, W.; Anders, S. Moderated estimation of fold change and dispersion for RNA-seq data with DESeq2. Genome Biol. 2014, 15, 550. [CrossRef] 
61. Robinson, M.D.; McCarthy, D.J.; Smyth, G.K. edgeR: A bioconductor package for differential expression analysis of digital gene expression data. Bioinformatics 2010, 26, 139-140. [CrossRef] [PubMed]

62. Ishiyama, M.; Miyazono, Y.; Sasamoto, K.; Ohkura, Y.; Ueno, K. A highly water-soluble disulfonated tetrazolium salt as a chromogenic indicator for NADH as well as cell viability. Talanta 1997, 44, 1299-1305. [CrossRef]

63. Tominaga, H.; Ishiyama, M.; Ohseto, F.; Sasamoto, K.; Hamamoto, T.; Suzuki, K.; Watanabe, M. A water-soluble tetrazolium salt useful for colorimetric cell viability assay. Anal. Commun. 1999, 36, 47-50. [CrossRef]

(C) 2020 by the authors. Licensee MDPI, Basel, Switzerland. This article is an open access article distributed under the terms and conditions of the Creative Commons Attribution (CC BY) license (http://creativecommons.org/licenses/by/4.0/). 